\title{
Molecular cloning, expression, and characterization of four novel thermo-alkaliphilic enzymes retrieved from a metagenomic library
}

\author{
Mukil Maruthamuthu* ${ }^{*}$ and Jan Dirk van Elsas
}

\begin{abstract}
Background: Enzyme discovery is a promising approach to aid in the deconstruction of recalcitrant plant biomass in an industrial process. Novel enzymes can be readily discovered by applying metagenomics on whole microbiomes. Our goal was to select, examine, and characterize eight novel glycoside hydrolases that were previously detected in metagenomic libraries, to serve biotechnological applications with high performance.

Results: Here, eight glycosyl hydrolase family candidate genes were selected from metagenomes of wheat strawdegrading microbial consortia using molecular cloning and subsequent gene expression studies in Escherichia coli. Four of the eight enzymes had significant activities on either $p N P$ - $\beta$-D-galactopyranoside, $p N P-\beta$-D-xylopyranoside, pNP-a-L-arabinopyranoside or $p N P$-a-D-glucopyranoside. These proteins, denoted as proteins 1, 2, 5 and 6, were histag purified and their nature and activities further characterized using molecular and activity screens with the $p$ NPlabeled substrates. Proteins 1 and 2 showed high homologies with (1) a $\beta$-galactosidase (74\%) and (2) a $\beta$-xylosidase (84\%), whereas the remaining two (5 and 6) were homologous with proteins reported as a diguanylate cyclase and an aquaporin, respectively. The $\beta$-galactosidase- and $\beta$-xylosidase-like proteins 1 and 2 were confirmed as being responsible for previously found thermo-alkaliphilic glycosidase activities of extracts of $E$. coli carrying the respective source fosmids. Remarkably, the $\beta$-xylosidase-like protein 2 showed activities with both $p N P$-Xyl and $p N P$-Ara in the temperature range $40-50^{\circ} \mathrm{C}$ and $\mathrm{pH}$ range $8.0-10.0$. Moreover, proteins 5 and 6 showed thermotolerant a-glucosidase activity at $\mathrm{pH}$ 10.0. In silico structure prediction of protein 5 revealed the presence of a potential "GGDEF" catalytic site, encoding a-glucosidase activity, whereas that of protein 6 showed a "GDSL" site, encoding a 'new family' a-glucosidase activity.
\end{abstract}

Conclusion: Using a rational screening approach, we identified and characterized four thermo-alkaliphilic glycosyl hydrolases that have the potential to serve as constituents of enzyme cocktails that produce sugars from lignocellulosic plant remains.

Keywords: Recombinant glycoside hydrolases, Thermo-alkaliphilic enzymes, Galactosidase, Biomass pretreatment, Biotechnological application

\section{Background}

Plant biomass is considered to represent a sustainable source of sugars for biofuel production via fermentation.

\footnotetext{
*Correspondence: m.marutha.muthu@rug.nl

Department of Microbial Ecology, Groningen Institute for Evolutionary Life Sciences, University of Groningen, Nijenborgh 7, 9747AG Groningen, The Netherlands
}

In this biomass, lignocellulosic material is the key source of 'renewable' energy [1]. Lignocellulose consists of the major compounds cellulose (40-50\%) and hemicellulose (25-30\%), next to lignin [2]. Hemicellulose is composed of different pentose (xylose, arabinose) and hexose (mannose, galactose, glucose) sugars that are linked by $\alpha$ - and/ or $\beta$-glycosidic bonds [3]. All of these sugars are widely 
used in biotechnology to produce bio-based materials, such as biofuels, plastics and other chemicals $[4,5]$. In particular, hemicellulases are key to the degradation of plant biomass; the hemicellulose fraction of the plant biomass represents a rich source of D-xylose, which is considered to constitute a key sugar for further biotechnological approaches. Thus, in the light of the currently still imperfect substrate unlocking approaches [6], a great interest has arisen to enhance the industrial enzymemediated lignocellulose hydrolysis methods [7], with hemicellulose as a prime target.

Different sets of hydrolytic enzymes (glycosyl hydrolases) are likely required for the complete deconstruction of hemicellulose compounds in order to obtain a mixture of sugars. In nature, communities of microorganisms, which include fungi and bacteria, often produce mixtures of glycosyl hydrolases (GHases) that complete the lignocellulose breakdown processes $[8,9]$. Moreover, to increase the efficiency of industrial hydrolysis for lignocellulose breakdown, multi-species microbial consortia play vital roles [10-12]. However, despite large research efforts over the past decade, our limited understanding of how the glycosyl hydrolases and their associated enzymes and/or proteins function together to break down lignocellulosic materials remains a key limitation for many applications [13].

In a previous study, we constructed fosmid libraries from two wheat straw-degrading microbial consortia, which were subsequently screened for the presence of genes for (hemi)cellulose-degrading enzymes using a multi-substrate approach [14]. In this endeavor, we screened for the presence of genes encoding 12 different GH family proteins (using CAZy database annotation), which were considered to possess the desired enzymatic activities, i.e., $\beta$-galactosidase, $\beta$-xylosidase and $\alpha$-glucosidase. Heat- and alkali-tolerant enzymatic activities were found with extracts produced from four E. coli fosmid clones, denoted NT2-2, T4-1, T5-5 and NT18-17 [14]. The first three clones were identified as containing genes encoding proteins with $\beta$-galactosidase and $\beta$-xylosidase activities. On the other hand, clone NT18-17 presumably carried a gene for a protein with $\alpha$-glucosidase activity, next to those for other glycoside hydrolase family enzymes, as predicted by CAZy database annotation. One more fosmid clone, 10BT, revealed enzymatic activity with mixtures of four substrates; in it, genes for proteins of families GH39 and GH53 were identified. However, the work with these five fosmid clones, into each of which up to $35 \mathrm{~kb}$ of metagenomic DNA (encompassing up to 30 genes), was cloned, precluded the precise determination of the exact function of each of the predicted proteins.

In the current study, we selected eight genes from the aforementioned five fosmid clones, of which three were predicted to produce enzymes with novel thermoalkaliphilic activity. The genes were subcloned in the pET28b(+) expression vector and (over)expressed in $E$. coli, after which the gene products were purified and biochemically characterized. The study explored, confirmed and refined the hypothesis that the selected proteins indeed have the thermo-alkaliphilic activities predicted from our previous study [14]. The characterization and in vitro studies identified two new glycoside hydrolase family enzymes with $\alpha$-glucosidase activities.

\section{Methods \\ Cloning system}

Cloning vector pET28b(+) (Novagen, Amsterdam, The Netherlands) was used for the expression of the selected genes. Escherichia coli JM109 competent cells (Promega, Leiden, The Netherlands), as well as BL21(DE3) and Origami2 (DE3) pLysS cells (Novagen, Amsterdam, The Netherlands) were used as host strains for cloning and expression studies. Restriction enzymes (EcoR1, BamH1, HindIII, and Xho1) and T4-DNA ligase were purchased from Fermentas (Amsterdam, The Netherlands) and used in accordance with the manufacturer's instructions.

\section{Extraction of DNA and molecular cloning into expression plasmids}

Selected E. coli EPI 300 fosmid clones NT2-2, T4-1, T5-5, NT18-17 and 10BT (Fig. 1) were cultured in $4 \mathrm{ml}$ of Luria Broth (LB) supplemented with $12.5 \mu \mathrm{l} / \mathrm{ml}$ chloramphenicol $(\mathrm{Cm}$; Sigma-Aldrich Chemie B. V, Zwijndrecht, The Netherlands). Then, fosmid DNA was extracted as described [14]. PCR primers were designed in regions outside of each gene, adding specific restriction sites to their $5^{\prime}$-ends (Table 1). Thus, full-length genes were generated from the clones by each PCR [Initial denaturation at $98^{\circ} \mathrm{C}$ for $30 \mathrm{~s}$ followed by 35 cycles of $10 \mathrm{~s}$ at $98^{\circ} \mathrm{C}, 30 \mathrm{~s}$ at $64{ }^{\circ} \mathrm{C}$, and $1.5 \mathrm{~min}$ at $72{ }^{\circ} \mathrm{C}$, with a final extension step of $72{ }^{\circ} \mathrm{C}$ (for $10 \mathrm{~min}$ )]. The PCR products were digested with selected restriction enzymes and then analyzed on $1 \%$ agarose gels. All patterns were in conformity with the predicted ones (Table 1). Then, full PCR products were run on gel and recovered from it using the Zymoclean ${ }^{\mathrm{TM}}$ Large Fragment DNA recovery kit (Zymo Research, Irvine, USA). Following recovery and purification, each DNA fragment was then ligated into expression vector pET28b $(+)$, which was followed by transformation of Escherichia coli JM109 competent cells (Promega. Leiden, The Netherlands).

\section{Verification of inserts, and expression and purification of target proteins}

All transformations were successful, and so eight recombinant constructs were produced. The success of cloning 


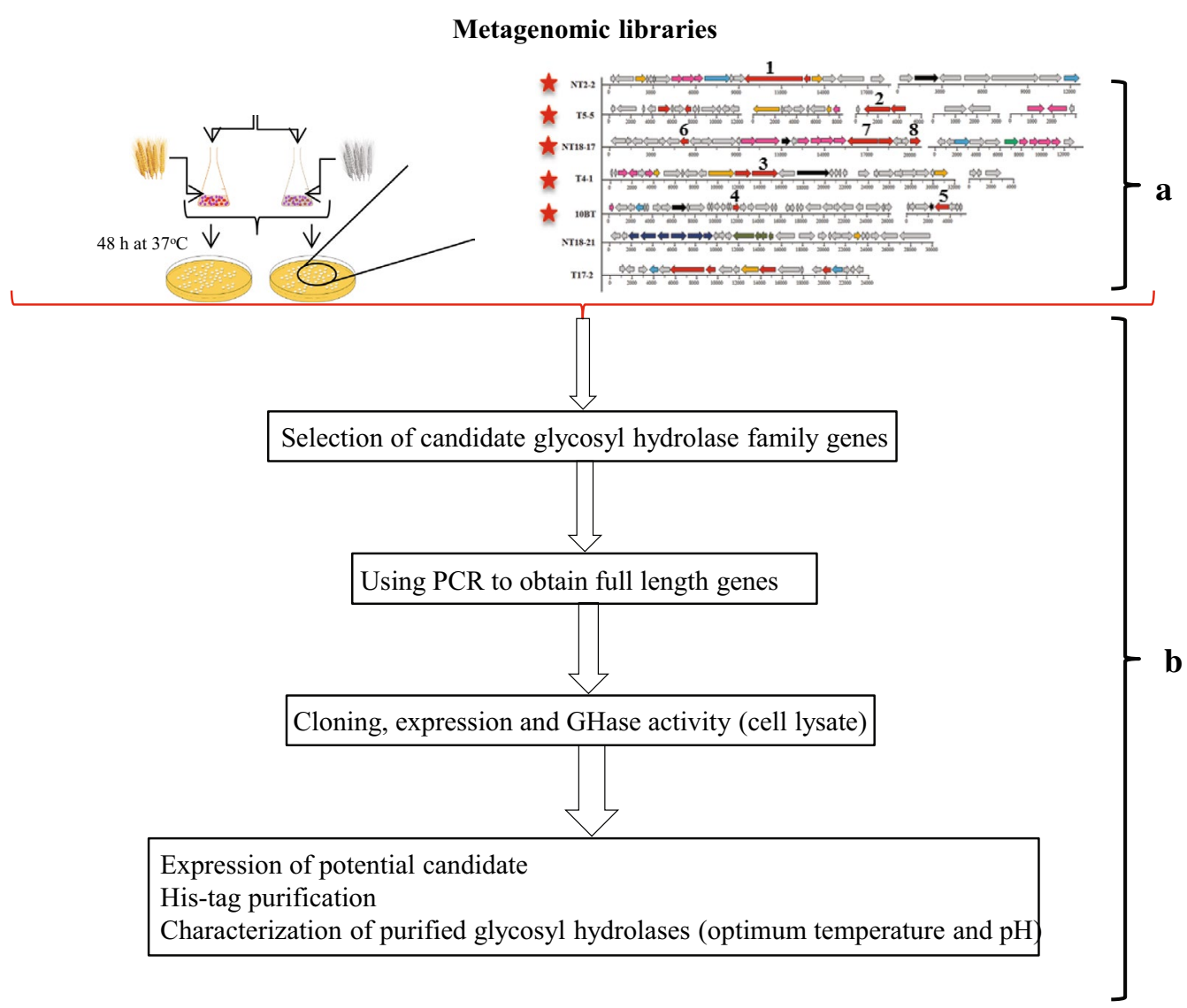

Fig. 1 Candidate gene selection and cloning strategy used in this study. a. Selected candidate genes from functional screening of fosmid libraries [14]. b. Experimental setup

was further confirmed by colony PCR with the respective primers (Table 1), yielding single amplicons of the expected sizes for all genes (Table 1). This was followed by single and double restriction of the constructs with the relevant enzymes (Table 1). Thus, EcoR1/BamH1 was used for gene 1 (3146 bp); HindIII/BamH1 for gene $2(2.4 \mathrm{~kb})$; EcoR1/HindIII for gene $3(2.4 \mathrm{~kb})$; BamH1/Xho1 for gene 4 and gene 8 (size of 624 bp and $1134 \mathrm{bp}$, respectively), and HindIII/BamH1 for gene $5(1.2 \mathrm{~kb})$, gene $6(673 \mathrm{bp})$, and gene $7(2.0 \mathrm{~kb})$. Clones carrying the selected eight genes were then selected and purified, after which they were used to inoculate $4 \mathrm{ml}$ LB tubes supplemented with $50 \mu \mathrm{g} / \mathrm{ml}$ of kanamycin (to select for the maintenance of the plasmid with insert). Tubes were incubated at $37{ }^{\circ} \mathrm{C}$ (shaking at $220 \mathrm{rpm}$ ) for 16-19 h. Following incubation, plasmid extraction was carried out using the QIAprep Spin Miniprep Kit (Qiagen, The Netherlands). All recombinant plasmids had the expected inserts; they were further checked by digestion with the aforementioned enzymes and enzyme combinations. Then, the full plasmids were introduced into E. coli strains BL21(DE3) and Origami2 (DE3) pLysS
(Novagen, Amsterdam, The Netherlands) competent cells, via transformation. These two strains facilitate the testing of the expression of the cloned genes. Selected transformants were purified and the presence of the correct inserts verified. They were then grown in kanamycin $(50 \mu \mathrm{g} / \mathrm{ml})$-supplemented 2X-PY medium (2 ml; $16 \mathrm{~g}$ Bacto-tryptone, $10 \mathrm{~g}$ yeast extract, $10 \mathrm{~g} \mathrm{NaCl} . \mathrm{H}_{2} \mathrm{O} / 1$, $\mathrm{pH} 8.0)$ at $37{ }^{\circ} \mathrm{C}(220 \mathrm{rpm}$, overnight $)$. A fresh $(200 \mathrm{ml})$ 2xPY flask was then inoculated, establishing an initial $\mathrm{OD}_{600}$ of 0.05 , after which the culture was grown at $37^{\circ} \mathrm{C}$ (shaking, $220 \mathrm{rpm}$ ) to an $\mathrm{OD}_{600}$ of 0.5-0.6. Afterwards, the culture was incubated for $1 \mathrm{~h}$ at $18{ }^{\circ} \mathrm{C}$ (shaking, $220 \mathrm{rpm}$ ), after which gene expression was induced by adding isopropyl $\beta$-D-1-thiogalactopyranoside (IPTG) at $0.5 \mathrm{M}$. Then, the culture was further incubated at $18{ }^{\circ} \mathrm{C}$ for $16-19 \mathrm{~h}$, after which cells were harvested at $4000 \times g$ $\left(4{ }^{\circ} \mathrm{C}, 15 \mathrm{~min}\right)$. The pellets were resuspended in $5 \mathrm{ml}$ of lysis buffer (50 mM HEPES, pH 8.0, $300 \mathrm{mM} \mathrm{NaCl}$, $50 \mu \mathrm{l} 1 \mathrm{M}$ DTT (1,4-Dithiothreitol), 1 protease inhibitor mini tablet (Roche, Sigma-Aldrich Chemie B. V, Zwijndrecht, The Netherlands) and the mixtures kept on ice for $15 \mathrm{~min}$. Then, cells were disrupted using sonification 
Table 1 List of selected genes, PCR primers, and predicted size

\begin{tabular}{|c|c|c|c|c|c|c|c|}
\hline $\begin{array}{l}\text { Fosmid } \\
\text { name }\end{array}$ & $\begin{array}{l}\text { Predicted enzyme } \\
\text { (Gene encoding) }\end{array}$ & Gene no. & Primers & $\begin{array}{l}\text { Restriction } \\
\text { enzymes }\end{array}$ & $\begin{array}{l}\text { Size } \\
\text { (bp) }\end{array}$ & $\begin{array}{l}\text { Approx. } \\
\text { size }(\mathrm{kDa})\end{array}$ & $\begin{array}{l}\text { Closet hit (identity/ } \\
\text { coverage) }\end{array}$ \\
\hline NT2-2 & $\beta$-Galactosidase & 1 & $\begin{array}{l}\text { FP-TACgaattcACGGCATCAGCGCAATAGTC } \\
\text { RP-AGggatccCGCTTCGCAACTGAGGTTAC }\end{array}$ & $\begin{array}{l}\text { EcoRl } \\
\text { BamHI }\end{array}$ & 3146 & 116 & $\begin{array}{l}\text { Enterobacterhormae- } \\
\quad \text { chei }(74 / 81 \%)\end{array}$ \\
\hline T5-5 & $\beta$-Xylosidase & 2 & $\begin{array}{l}\text { FP-GCGaagcttGTGTAGTCTTTGCCCATCTC } \\
\text { RP-CAGggatccCGCTTCGCAACTGAGGTTAC }\end{array}$ & $\begin{array}{l}\text { HindllII } \\
\text { BamHI }\end{array}$ & 2410 & 85 & $\begin{array}{l}\text { Enterobacter } \\
\text { mori (83/90\%) }\end{array}$ \\
\hline T4-1 & $\beta$-Xylosidase & 3 & $\begin{array}{l}\text { FP-GCGgaattcCACCAGATTCAGCCCTACAG } \\
\text { RP-CAGaagcttTGTAGTCTTTGCCCATCTCC }\end{array}$ & $\begin{array}{l}\text { EcoRl } \\
\text { HindllI }\end{array}$ & 2439 & 86 & $\begin{array}{l}\text { Enterobacter } \\
\text { mori (83/90\%) }\end{array}$ \\
\hline \multirow[t]{2}{*}{ 10BT } & $\begin{array}{l}\text { Transcription } \\
\text { regulator }\end{array}$ & 4 & $\begin{array}{l}\text { FP-GCGggatccGCACAACAAGATGGCTTTAC } \\
\text { RP-CAGctcgagTAGTCGCATTTTGACGGAAC }\end{array}$ & $\begin{array}{l}\text { BamHI } \\
\text { Xhol }\end{array}$ & 627 & 22 & $\begin{array}{l}\text { Klebsiella oxy- } \\
\text { toca }(76 / 87 \%)\end{array}$ \\
\hline & $\begin{array}{l}\text { Inner membrane } \\
\text { protein }\end{array}$ & 5 & $\begin{array}{l}\text { FP-GCGaagcttGTGCAAAGTATCGCTTTAAC } \\
\text { RP-CAGggatccAGCAGCATGAATAAGGACAC }\end{array}$ & $\begin{array}{l}\text { HindllII } \\
\text { BamHI }\end{array}$ & 1262 & 45 & $\begin{array}{l}\text { Enterobacter cloa- } \\
\text { cae }(79 / 88 \%)\end{array}$ \\
\hline \multirow[t]{3}{*}{ NT18-17 } & Aquaporin & 6 & $\begin{array}{l}\text { FP-GCGaagcttGGGATCGGCTAGATCTTGAG } \\
\text { RP-CAGggatccCAAGCGTCATGAATAAACTG }\end{array}$ & $\begin{array}{l}\text { HindllII } \\
\text { BamHI }\end{array}$ & 673 & 22 & $\begin{array}{l}\text { Hyphomonas neptu- } \\
\text { nium }(65 / 80 \%)\end{array}$ \\
\hline & $\begin{array}{l}\text { Beta-hexosamini- } \\
\text { dase }\end{array}$ & 7 & $\begin{array}{l}\text { FP-GCGggatccTTTGCGGAGCCTACTCCTTC } \\
\text { RP-CAGaagcttTTACAATGGCATCTGATTGG }\end{array}$ & $\begin{array}{l}\text { BamHI } \\
\text { Hindlll }\end{array}$ & 1944 & 70 & $\begin{array}{l}\text { Rhizobium legumino- } \\
\text { sarum } \\
3841(50 / 64 \%)\end{array}$ \\
\hline & $\begin{array}{l}\text { Hypothetical } \\
\text { protein }\end{array}$ & 8 & $\begin{array}{l}\text { FP-GCGggatccCCGGATACTCCACACAAAGG } \\
\text { RP-CAGctcgagTTATCGCAAGTCGATCAAGG }\end{array}$ & $\begin{array}{l}\text { BamHl } \\
\text { Xhol }\end{array}$ & 1134 & 37 & $\begin{array}{l}\text { Hyphomicrobium deni- } \\
\text { trificans }(56 / 71 \%)\end{array}$ \\
\hline
\end{tabular}

with the following parameters: 40 cycles $-6 \mathrm{~s}$ on $/ 15 \mathrm{~s}$ off-amplitude 6-10 $\mu \mathrm{m}$. After this treatment, the resulting cell lysates were centrifuged at $15,000 \mathrm{~g}$ for $15 \mathrm{~min}$ at $4{ }^{\circ} \mathrm{C}$. The supernatants were removed and stored, and $10 \mu$ l was checked with $12 \%$ SDS-PAGE (sodium dodecyl sulfate polyacrylamide gel electrophoresis), followed by staining with the Pierce ${ }^{\mathrm{TM}} 6 \mathrm{xHis}$ protein tag stain reagent set (Thermo Fisher Scientific, Waltham, USA). The preparation was then heated to $60{ }^{\circ} \mathrm{C}$ for $15-20 \mathrm{~min}$ and centrifuged at $15,000 \times g$ to remove insoluble debris. Purification of his-tagged proteins from the crude extracts was then carried out by gravity flow chromatography through agarose. Thus, $600 \mu \mathrm{l}$ of Ni-NTA agarose (Qiagen, Hilden, Germany) was added to $10 \mathrm{ml}$ of lysis buffer. Incubation was for 5 min (shaking, $4{ }^{\circ} \mathrm{C}$ ), before the mixture was centrifuged for $5 \mathrm{~min}$ at $800 \mathrm{~g}$ at $4{ }^{\circ} \mathrm{C}$. The supernatant was discarded and then $10 \mathrm{ml}$ of equilibration buffer (50 mM HEPES and $300 \mathrm{mM}$ $\mathrm{NaCl}$ ) was added, after which the mixture was incubated as mentioned above. A short spin followed. Then, the crude extract was added to the resin and incubated for $1 \mathrm{~h}$ before it was transferred into a gravity flow column and incubated at $4{ }^{\circ} \mathrm{C}$ until the resin bed settled down. The cell-free lysates were removed by gravity flow and unbound proteins were washed 3 times with $10 \mathrm{ml}$ of wash buffer (50 mM HEPES, $300 \mathrm{mM} \mathrm{NaCl}, 20 \mathrm{mM}$ Imidazole). The bound enzyme was eluted with $3 \mathrm{ml}$ of elution buffer (50 mM HEPES, $300 \mathrm{mM} \mathrm{NaCl}, 400 \mathrm{mM}$ Imidazole). The enzyme samples were concentrated using Amicon ultra-15 centrifugal filter units (Millipore, Amsterdam, The Netherlands) and quantified using the Bradford method (Bradford 1X dye, Biorad, Veenendaal, The Netherlands). The purity was then analyzed by running 12\% SDS-PAGE followed by staining with Pierce $^{\mathrm{TM}} 6 \mathrm{xHis}$ protein tag stain reagent Set (Fig. 2).

\section{Substrate specificity testing}

Fifty microliter volumes containing approximately $0.6 \mu \mathrm{g}$ of enzyme were used for testing enzyme activity on 3,5 and $10 \mathrm{mM}$ of $p \mathrm{NP}$ substrate ( $p \mathrm{NP}-\beta$-D-galactopyranoside, $p$ NP- $\beta$-D-xylopyranoside, $\quad p$ NP- $\alpha$-L-arabinopyranoside, and $p \mathrm{NP}-\alpha$-D-glucopyranoside) (Sigma-Aldrich Chemie B. $\mathrm{V}$, Zwijndrecht, The Netherlands). Fifty $\mathrm{mM}$ of Tris $-\mathrm{HCl}$ buffer- $\mathrm{pH} 7.5$ was used in the ratio of 1:1. The reaction mixture was incubated at $40^{\circ} \mathrm{C}$ for $0.5-1 \mathrm{~h}$, after which the reactions were deactivated on ice for $10 \mathrm{~min}$. To validate the enzyme activity, the experiments were controlled with (i) water and substrate, (ii) enzyme with water, and (iii) host protein lysate with substrate. The concentration of released $p \mathrm{NP}$ was determined by measuring the reaction mixture absorbance at $410 \mathrm{~nm}$ using a calibration curve, as explained [14]. Effects of temperature and $\mathrm{pH}$ on hydrolysis activity for all recombinant enzymes were evaluated. For temperature, we used the range $10-70{ }^{\circ} \mathrm{C}$ at $\mathrm{pH} 7.5$. For $\mathrm{pH}$, we used the range $4.0-10.0$ at $50{ }^{\circ} \mathrm{C}$, using sodium citrate buffer ( $\mathrm{pH} 4.0$ and 5.0), Tris- $\mathrm{HCl}(\mathrm{pH} \mathrm{7.5,} \mathrm{8.0,} \mathrm{and}$ 9.0), and glycine- $\mathrm{NaOH}$ buffer ( $\mathrm{pH} 10.0$ ).

Kinetic parameters $\left(K_{\mathrm{m}}\right.$ and $\left.V_{\max }\right)$ for all purified recombinant enzymes (protein 1, 2, 5 and 6) were evaluated by measuring the enzyme activity using $0-10 \mathrm{mM}$ of respective $p \mathrm{NP}$ as substrate in $50 \mathrm{mM}$ Tris- $\mathrm{HCl}$ buffer ( $\mathrm{pH} 7.5)$ at $40{ }^{\circ} \mathrm{C}$ for $15 \mathrm{~min}$. The data were plotted according to the Lineweaver-Burk method to calculate $K_{\mathrm{m}}$ and $V_{\max }$ values. For thermal stability assays, the purified enzymes were pre-incubated at $50{ }^{\circ} \mathrm{C}$ (according to preliminary data) in the absence of $p \mathrm{NP}$ substrates. After incubation for 
different time periods $(0,15,30,120$ and $180 \mathrm{~min})$, enzymatic activity was measured for each enzyme with specific $p \mathrm{NP}$ substrate, temperature and $\mathrm{pH}$. The inhibitory effect of different concentrations (0-1.0\%) of 5-hydroxymethylfurfural (5-HMF) and furfural was determined by incubating all enzymes (protein 1, 2, 5 and 6) with respective series of $p \mathrm{NP}$ dissolved in $50 \mathrm{mM}$ Tris- $\mathrm{HCl}$ buffer $(\mathrm{pH}$ 7.5). For the lignocellulose hydrolysis, the reaction mixtures contained $20 \mathrm{mg}$ of raw wheat straw (RWS) substrate with the enzyme (protein 1, 2, 5, 6 and mixed) treatment, adjusted to $1.5 \mathrm{ml}$ with sodium phosphate buffer $(0.1 \mathrm{M}$, $\mathrm{pH}$ 6.0). The experiments were carried out at $50{ }^{\circ} \mathrm{C}(12-$ $24 \mathrm{~h}$, shaking at $250 \mathrm{rpm})$. After incubation, the mixtures were centrifuged $\left(12,000 \times g\right.$ for $15 \mathrm{~min}$ at $\left.4{ }^{\circ} \mathrm{C}\right)$, and the supernatants collected. The amount of total reducing sugars in the supernatants was measured by the dinitrosalicylic acid (DNS) colorimetric method.

\section{Activity of selected enzymes in the presence of different ions}

The effects of $\mathrm{MgCl}_{2}, \mathrm{MnCl}_{2}$ (5 and $20 \mathrm{mM}$ ), and $\mathrm{NaCl}$ (20 and $2000 \mathrm{mM}$ ) were assessed by measuring enzyme

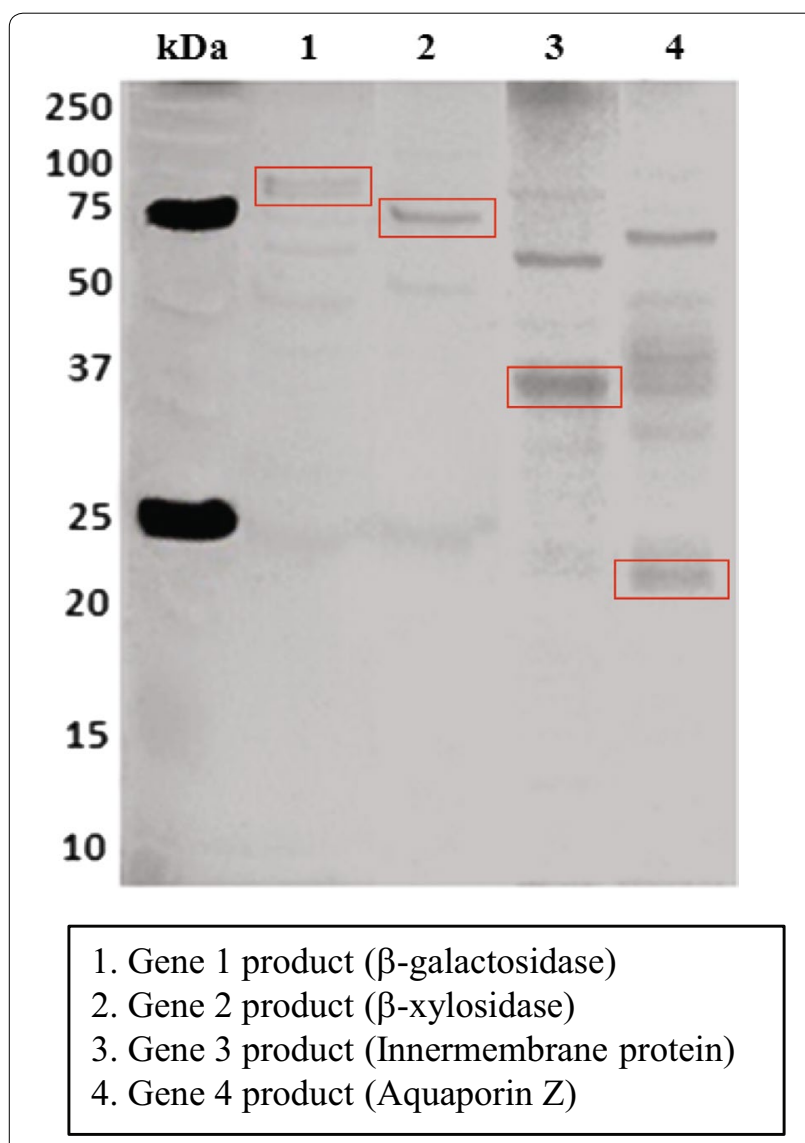

Fig. 2 Analysis of His-tag purified proteins. Four selected proteins were checked using 12\% SDS-PAGE activities with specific substrates in the presence versus absence of these additives. Given the potential importance for application, we used a range of $\mathrm{pH}(4.0-10.0)$ and temperatures $\left(40-50{ }^{\circ} \mathrm{C}\right)$. Statistical comparisons among samples were performed using one-way ANOVA (Tukey's test) using the software Past3 (http://folk.uio. no/ohammer/past/).

\section{Amino acid sequence and structure analyses of the gene 5 and 6 products}

The products of genes 5 and 6 (proteins 5 and 6) were investigated for homology with proteins in the nonredundant protein database (http://www.ncbi.nlm.nih. gov) using BLAST-P [15]. In addition, protein domains were characterized by searching the protein family database Pfam [16]. The two proteins were initially annotated as (1) a diguanylate cyclase and (2) an aquaporin $\mathrm{Z}$. For each gene, a multiple sequence alignment was constructed using COBALT, a tool that finds a collection of pairwise constraints derived from conserved domain database, protein motif database and sequence similarity, using RPS-BLAST, BLAST-P and PHI-BLAST [17]. In addition, domain analyses were done for function prediction by the conserved domain architecture retrieval tool (CDART) [18].

\section{Structure analyses}

We used Phyre2 to reconstruct the tertiary structures of proteins 5 and 6 [19]. Next, we generated a list of proteins with structural similarities to the protein models using the Dali server [20]. A three-dimensional model of the best three matches for each protein was retrieved from the Protein Data Bank (PDB) [21]. For protein 5, these matches were: activated response regulators, namely a signaling protein [PDB: 1W25], a transferase [PDB: 2WB4], and a lyase [2V0N] from Caulobacter vibrioides (Alphaproteobacteria). For protein 6, the matches were membrane proteins (porins) from Agrobacterium fabrum [PDB: 3LLQ] and Escherichia coli [PDB: 2O9D] and a transport protein, also from $E$. coli [PDB: 3NKA]. Further manipulations, structural alignments and comparisons between the 3D models of the proteins were completed using PyMOL (http://www.pymol.org).

\section{Results}

Selection of genes encoding glycosyl hydrolases from five fosmid clones

In our previous study, we successfully screened two metagenomic libraries generated from wheat strawdegrading microbial consortia produced by the dilution-to-stimulation approach for genes encoding (hemi) cellulose-degrading enzymes [14]. In total, we identified 18 genes for proteins belonging to 12 different glycosyl 
hydrolase (GH) families and another 21 genes for carbohydrate-active enzymes (CBMs, AAs, GTs, and CEs; as evidenced by CAZy database annotation), in seven fosmid clones. Five of these fosmid clones, notably NT2-2, T4-1, T5-5, 10BT and NT18-17, were selected here in order to study their enzyme activities in greater detail and match structure with function. Thus, eight genes, denoted genes 1 through 8, encoding putative GHases, were initially selected in these clones (Table 1). This was done on the basis of homologies with genes for known $\mathrm{GH}$ active enzymes, as well as protein sizes. Interestingly, three of the five selected fosmid clones, denoted NT2-2, T5-5 and NT18-17, had been predicted to encode putative thermo-alkaliphilic enzymes [14].

Here, we provide the specifics of the eight selected genes. Gene 1 (fosmid NT2-2) was annotated as a gene for a family GH2 $\beta$-galactosidase (EC. 3.2.1.23), with a molecular size of $\sim 116 \mathrm{kDa}$. Its predicted amino acid sequence revealed $74 \%$ identity with a $\beta$-galactosidase of Enterobacter hormaechei by Blast-P. Genes 2 (fosmid T5-5) and 3 (fosmid T4-1) were both predicted to encode a family GH3 $\beta$-xylosidase of $\sim 86 \mathrm{kDa}$ (EC. 3.2.1.37; tracked to Enterobacter mori with identities of 84 and $83 \%$, respectively). These two genes revealed $86 \%$ identity between them. The remaining five genes, i.e., genes 4 and 5 (source fosmid 10BT) and 6, 7 and 8 (source fosmid NT18-17), were predicted to encode enzymes belonging to CAZy families GH39, GH53, GH27, GH20 and GH58, respectively. Blast-P comparisons showed homologies of the predicted gene products with a suite of different proteins, i.e. a transcriptional regulator of the AraC family (protein 4; GH39; 76\% identity; organism Klebsiella oxytoca), an inner membrane protein (protein 5; GH53; 79\% identity; Enterobacter cloacae), an aquaporin Z (protein 6; GH27; 65\% identity; Hyphomonas neptunium), a beta-hexosaminidase (protein 7; GH20; 50\% identity; Rhizobium leguminosarum), and a hypothetical protein (protein 8; GH58; 56\% identity; Hyphomicrobium denitrificans), respectively (Table 1).

\section{Characterization of cloned genes and gene expression}

The eight selected genes (Table 1) were all cloned into the pET28b $(+)$ vector [22], with polyhistidine-tag sequences at both the $\mathrm{N}$ and $\mathrm{C}$ termini. All genes were, thus, successfully introduced into E. coli strains BL21(DE3) and Origami2 (DE3) pLysS. To confirm the fidelity of the cloning, the pET28b(+) plasmids with inserts were extracted from selected clones, per gene, of each of the two strains and the presence of the cloned fragments detected by restriction with specific restriction enzymes followed by gel electrophoresis. The observed sizes of the restriction fragments (data not shown) were consistent with the fragment sizes as predicted from the fosmidderived gene sequences (Table 1 ).
Expression of the eight cloned genes was then investigated using extracts of grown cultures of both $E$. coli transformant strains (BL21(DE3) and Origami2 (DE3) pLysS) in 2x-PY medium, following induction by IPTG. Both the cell and the soluble fractions (culture supernatants) were used in the tests. We investigated the effects of IPTG concentration $(0.25,0.5$ and $1 \mathrm{mM})$, temperature $\left(18,30\right.$ and $37{ }^{\circ} \mathrm{C}$; at $\left.200 \mathrm{rpm}\right)$, and glucose concentration $(0.25,0.5,0.75$ and $1 \mathrm{mM})$ on the gene expression levels. In strain BL21(DE3), the target proteins were, unfortunately, mostly found in the cell fractions, except the product of gene 2 , where $~ 50 \%$ of protein occurred in the soluble fraction (data not shown). In contrast, the use of E. coli Origami2 (DE3) pLysS resulted in seven of the eight proteins being present in the soluble fractions, albeit at different levels. Unfortunately, the single remaining protein (product of gene 4) was only detectable in the cell fraction. The collective data revealed that maximal protein production took place, in the selected strain $E$. coli Origami2 (DE3) pLysS, with $0.5 \mathrm{mM} \mathrm{IPTG}$ at $18{ }^{\circ} \mathrm{C}$, in the absence of glucose. This was true for all genes (data not shown).

We thus used the total protein-containing lysates of the cultures of E. coli Origami2 (DE3) pLysS for analysis of the selected seven gene products, i.e., proteins 1 , $2,3,5,6,7$ and 8 , on a series of $p$ NP-labeled substrates. Indeed, protein 1 revealed high activity on $p$ NP- $\beta$-Dgalactopyranoside, indicating beta-galactosidase-like activity. This was consistent with the activity that had previously been detected in its source fosmid NT2-2. Interestingly, the cultures of $E$. coli with cloned genes 2 and 3 both yielded soluble fractions that revealed dual activities, i.e. transformation of $p \mathrm{NP}-\beta-\mathrm{D}$-xylopyranoside ( $\beta$-xylosidase $)$ and $\quad p \mathrm{NP}-\alpha-\mathrm{L}$-arabinopyranoside $(\alpha$-arabinosidase). These genes had been selected from fosmid clones T5-5 and T4-1, respectively, which had previously shown high $\beta$-xylosidase activities, but had not shown $\alpha$-arabinosidase activity. Expectedly, the cultures with cloned gene 4 , with predicted $\beta$-xylosidase activity, did not yield lysates with any activity on the substrates used. Clearly, the expressed protein of gene 4 was in inclusion bodies, and unfortunately we were unsuccessful in several attempts to recover native forms of it by refolding. In fact, its source fosmid clone 10BT had previously been found to have the gene 4 encoded GH39 family protein linked to $\beta$-xylosidase activity [14]. Finally, proteins 5 and 6 [14]) both revealed activities towards $p \mathrm{NP}-\alpha$-D-glucopyranoside, and there was no detectable enzymatic activity with any of the other $p$ NP substrates (such as $p$ NP- $\beta$-D-xylopyranoside and $p$ NP$\alpha$-L-arabinopyranoside). Gene 5 had also been selected from fosmid clone 10BT, which had shown consistent enzyme activity on $p$ NP- $\beta$-D-xylopyranoside, but not on 
$\alpha$-D-glucopyranoside [14]. Gene 6, originating from fosmid clone NT18-17, yielded a product with $\alpha$-glucosidase activity, which was in line with the predicted activity in its source fosmid. Finally, and against our expectations, the total protein lysates of genes 7 (GH20 family- $\beta$ hexosaminidase; EC 3.2.1.52) and 8 (GH58 family-endo$\mathrm{N}$-acetylneuraminidase) did not reveal activities with any of the substrates.

For all further work, we selected the four genes 1, 2, 5 and 6 that had yielded soluble proteins with key promising activities, i.e. $\beta$-galactosidase, $\beta$-xylosidase and $\alpha$-glucosidase. Specifically, gene 2 was selected instead of the similar gene 3 , because our previous study showed that its mother fosmid clone, T5-5, had yielded extracts in which proteins with thermo-alkaliphilic $\beta$-xylosidase activity were present, whereas fosmid clone T4-1 (source for gene 3 ) showed only slight $\beta$-xylosidase activity [14].

\section{Enzyme sizing and activity}

We scaled up the production of the gene 1, 2, 5 and 6 products in order to obtain sufficient soluble protein for further testing. The products were thus purified from large overnight $E$. coli Origami2 (DE3) pLysS cultures containing copies of intact genes 1, 2, 5 and 6 in the $\mathrm{pET} 28 \mathrm{~b}(+)$ expression vector (see Fig. 2). The products of genes $1(\sim 116 \mathrm{kDa}), 2(\sim 85 \mathrm{kDa}), 5(\sim 45 \mathrm{kDa})$ and 6 $(\sim 22 \mathrm{kDa})$ had the predicted molecular sizes, as estimated from the polyacrylamide gels. The purified proteins were then further examined for GHase activity under various conditions of temperature $\left(10-70{ }^{\circ} \mathrm{C}\right)$ and $\mathrm{pH}(4.0-10.0)$, as discussed below and shown in Fig. 3 .

\section{Protein 1}

The activity of the gene 1 encoded protein was examined with $3 \mathrm{mM} p \mathrm{NP}-\mathrm{Gal}$ as the substrate. It was active over a temperature range from 30 to $50{ }^{\circ} \mathrm{C}$ (Fig. 3a), with maximal activity at $50{ }^{\circ} \mathrm{C}$, of $68.6 \mathrm{U} / \mathrm{mg}$. The effect of $\mathrm{pH}$ was then determined at $50{ }^{\circ} \mathrm{C}$ (Fig. 3b). Activity was observed in the $\mathrm{pH}$ range 4.0-10.0, with maximal activity at $\mathrm{pH} 8.0$ $(58.7 \mathrm{U} / \mathrm{mg})$. This activity did not decrease much at $\mathrm{pH}$ $9.0(98 \%)$ and $10.0(78 \%)$.

\section{Protein 2}

Initially, the gene 2 encoded protein was screened for enzymatic activity on $p$ NP-Xyl and $p$ NP-Ara (both $3 \mathrm{mM}$ ), revealing both activities. The purified enzyme was found to be active on $p \mathrm{NP}$-Xyl in the temperature range $40-60{ }^{\circ} \mathrm{C}$ (Fig. 3c), showing highest activity at $50{ }^{\circ} \mathrm{C}$, with the release of approximately $117.8 \mathrm{U} /$ $\mathrm{mg}$ of $p$-nitrophenol. As in Fig. 3d, activity was further observed between $\mathrm{pH} 6.0$ and 10.0, with maximal activity at $\mathrm{pH} 9.0$, at $50{ }^{\circ} \mathrm{C}$. The activity, overall, remained $>60 \%$ between $\mathrm{pH} 4.0$ and 10.0. On $p$ NP-Ara, the enzyme showed activity ( 16.8 U/mg) between 20 and $70{ }^{\circ} \mathrm{C}$, with maximal activity at $40{ }^{\circ} \mathrm{C}$ (Fig. 3e). We then checked the $\mathrm{pH}$ sensitivity of the enzyme using $p \mathrm{NP}$-Ara at $40{ }^{\circ} \mathrm{C}$, and found optimal activity at $\mathrm{pH}$ 6.0, with approximately $16.62 \mathrm{U} / \mathrm{mg}$ of $p$-nitrophenol being released (Fig. 3f).

\section{Protein 5}

To define the optimal temperature for the activity testing of protein 5 , tests were performed with $p$ NP- $\alpha-\mathrm{D}$ glucopyranoside $(10 \mathrm{mM})$ at $\mathrm{pH} 7.5$ and at temperatures ranging from 10 to $70{ }^{\circ} \mathrm{C}$. An optimal temperature of $50{ }^{\circ} \mathrm{C}$ for protein 5 activity was found (Fig. 3g). Moreover, the protein also released $30.6 \mathrm{U} / \mathrm{mg}$ of $p$-nitrophenol. The latter activity $\left(\right.$ at $\left.50^{\circ} \mathrm{C}\right)$ was maximal at $\mathrm{pH} 10.0$ (102.54 U/mg; Fig. 3h).

\section{Protein 6}

The gene 6 product was tested with $10 \mathrm{mM}$ of $p N P-\alpha-\mathrm{D}-$ glucopyranoside at $\mathrm{pH} 7.5$ and in a temperature range of 10 to $70{ }^{\circ} \mathrm{C}$. Protein 6 worked optimally at $40{ }^{\circ} \mathrm{C}$, with $6.97 \mathrm{U} /$ $\mathrm{mg}$ of $p$-nitrophenol being released (Fig. 3i). Furthermore, the enzyme showed maximal activity, i.e., $107.63 \mathrm{U} / \mathrm{mg}$ of p-nitrophenol being released, at $\mathrm{pH} 10.0$ (Fig. 3j), and this was slightly higher than the product of gene 5 .

\section{Comparison of gene 5 and gene 6 products}

The products of genes 5 and 6 showed similar enzymatic activities on $p \mathrm{NP}-\alpha$-D-glucopyranoside at $\mathrm{pH}$ 4.0-6.0 under the same conditions. Unexpectedly, the activities of both proteins 5 and 6 dropped to near zero at $\mathrm{pH}$ 8.0-9.0 (Fig. 3h, j). Moreover, protein 5 showed significantly higher $\alpha$-glucosidase activity $(30.6 \pm 0.17 \mathrm{U} / \mathrm{mg})$ than protein $6(6.9 \pm 0.36 \mathrm{U} / \mathrm{mg})$. The collective results suggest that the four selected genes encode proteins with different thermo-alkaliphilic activities, as they all were optimally functional at temperatures of $40-50{ }^{\circ} \mathrm{C}$ and $\mathrm{pH}$ values of up to 10.0 (Fig. 3).

The kinetic parameters of all enzymes were calculated from Lineweaver-Burk plots of specific activities at various substrate concentrations $(0-10 \mathrm{mM})$. The $K_{\mathrm{m}}$ and $V_{\max }$ values for protein 1 (with $p$ NP- $\beta$-Dgalactopyranoside) were $0.1 \mathrm{mM}$ and $58.8 \mathrm{U} / \mathrm{mg}$ and for protein 2 ( $p$ NP- $\beta$-D-xylopyranoside and $p N P-\alpha-$ L-arabinopyranoside) 1.0 and $0.3 \mathrm{mM}$, and 666.7 and $102 \mathrm{U} / \mathrm{mg}$, respectively. The $K_{\mathrm{m}}$ values of proteins 5 and 6 , with $p$ NP- $\alpha$-D-glucopyranoside, were 7.4 and $21.4 \mathrm{mM}$, and the $V_{\max }$ values were 196 and $588.2 \mathrm{U} / \mathrm{mg}$, respectively.

Stability of the selected enzymes at elevated temperatures In a second set of experiments, we determined the stabilities of the enzymes encoded by genes $1,2,5$ and 6 , at elevated temperatures. The gene 1 ( $p$ NP-Gal), 5 ( $p$ NP-Glu) 
$\mathbf{a}$

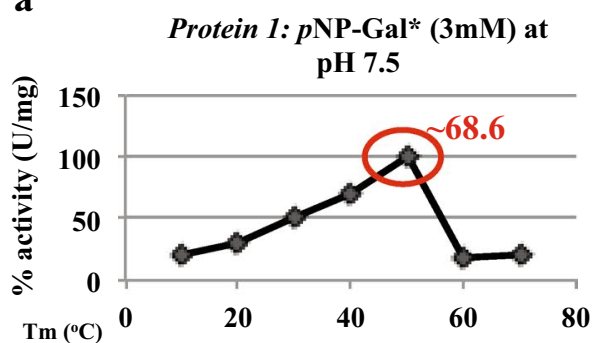

c

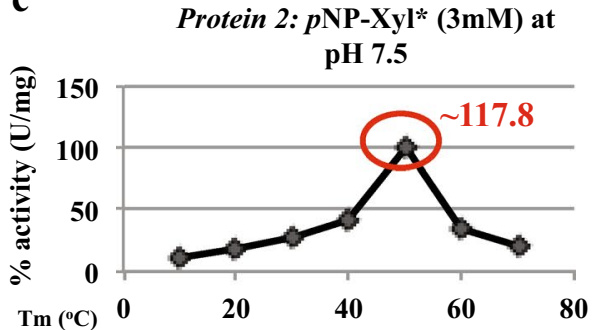

e
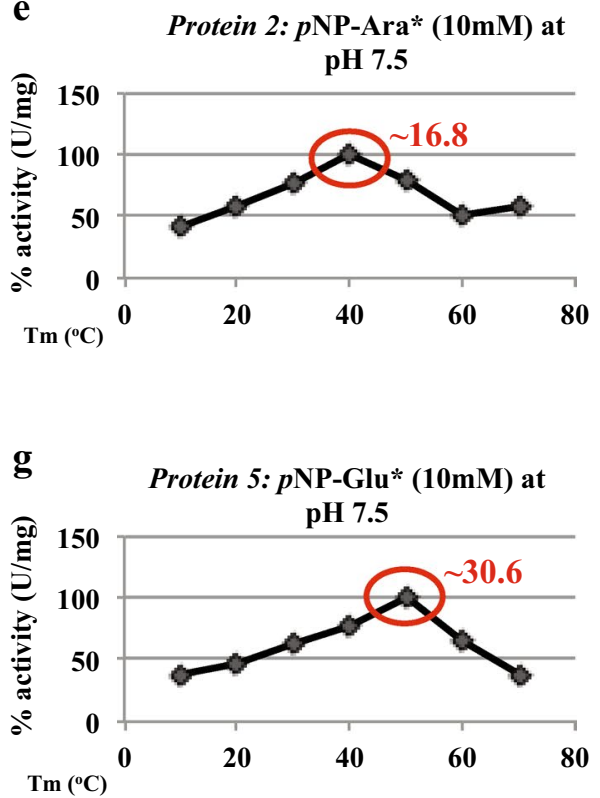

i

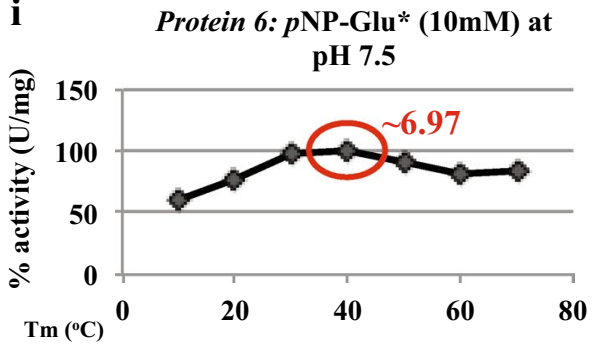

$\mathbf{b}$

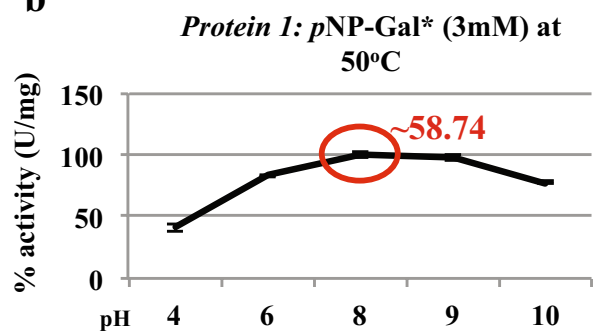

d

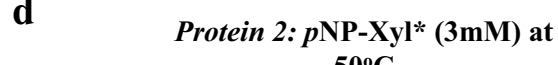
$5^{\circ} \mathrm{C}$

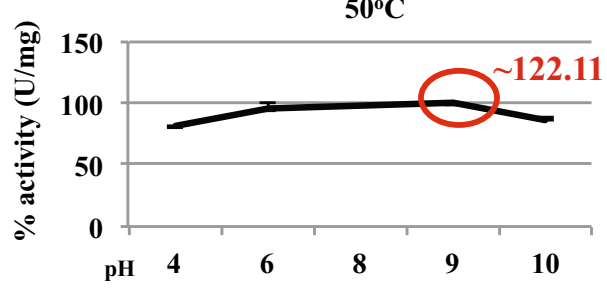

$\mathbf{f}$

Protein 2: pNP-Ara* $(3 \mathrm{mM})$ at $40^{\circ} \mathrm{C}$

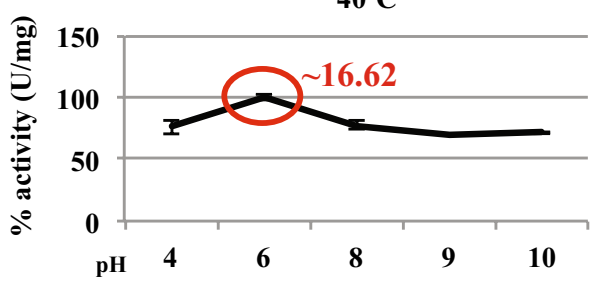

h
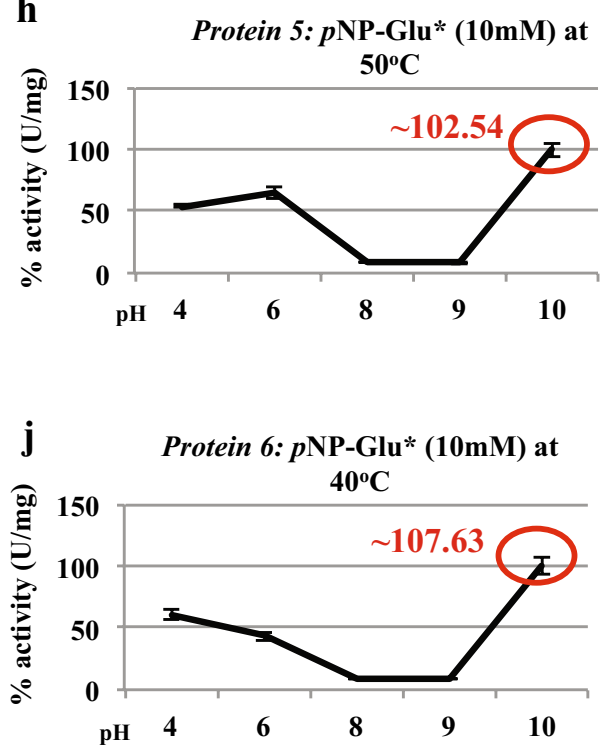
(See figure on previous page.)

Fig. 3 Characterization of four selected candidate GHases: Enzyme activities measured against pNP-substrates under different temperatures with constant $\mathrm{pH}$ and different $\mathrm{pH}$ with optimum temperature. Protein 1 with $\mathrm{pNP}-\beta-\mathrm{D}$-galactopyranoside $\mathbf{a} . \mathrm{Tm} 50^{\circ} \mathrm{C} ; \mathrm{pH} 7.5 ; 68.6 \mathrm{U} / \mathrm{mg}$ and $\mathbf{b}$. Tm $50^{\circ} \mathrm{C}$;

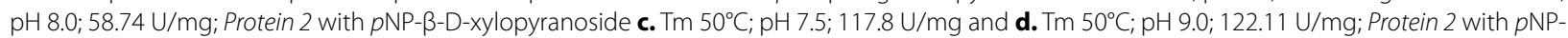
a-L-arabinopyranoside e. $\mathrm{Tm} 40^{\circ} \mathrm{C} ; \mathrm{pH} 7.5 ; 16.8 \mathrm{U} / \mathrm{mg}$ and f. $\mathrm{Tm} 40^{\circ} \mathrm{C} ; \mathrm{pH} 6.0 ; 16.62 \mathrm{U} / \mathrm{mg}$; Protein 5 with pNP-a-D-glucopyranoside g. Tm 50 $\mathrm{C} ; \mathrm{pH}$ 7.5; $30.6 \mathrm{U} / \mathrm{mg}$ and $\mathbf{h}$. $\mathrm{Tm} 50^{\circ} \mathrm{C} ; \mathrm{pH} 10.0 ; 102.54 \mathrm{U} / \mathrm{mg}$; Protein 6 with pNP-a Dglucopyranoside i. $\mathrm{Tm} 40^{\circ} \mathrm{C} ; \mathrm{pH} 7.5 ; 6.97 \mathrm{U} / \mathrm{mg}$ and j. Tm 40 $\mathrm{C} ; \mathrm{pH} 10.0$; $107.63 \mathrm{U} / \mathrm{mg}$

and 6 ( $p$ NP-Glu) products retained $95 \%$ of activity after over $120 \mathrm{~min}$ of incubation at $50{ }^{\circ} \mathrm{C}$, after which the activities decreased-at $180 \mathrm{~min}$ - to about $50 \%$ of the initial levels. At $50{ }^{\circ} \mathrm{C}$, the gene 2 product showed $100 \%$ activity with $p \mathrm{NP}-\mathrm{Xyl}$ for $15 \mathrm{~min}$, and then enzyme activity even increased, to over $180 \%$ of the control, maintaining the raised activity level until $180 \mathrm{~min}$. On $p \mathrm{NP}$-Ara, the gene 2 encoded protein retained 100\% activity for 30 min, showing a $20 \%$ increased activity in the period between 120 and $180 \mathrm{~min}$ (Fig. 4).

\section{Effects of inhibitors (5-HMF and furfural) and degradation of complex polysaccharide}

Two of the major inhibitors in lignocellulose hydrolysis, 5-hydroxymethyl furfural (HMF) and furfural were tested for their effects on the activity proteins $1,2,5$ and 6 using selected concentrations of $p \mathrm{NP}$ substrates ( $3 \mathrm{mM}$ of $p \mathrm{NP}$ Gal, $p$ NP-Xyl and $p$ NP-Ara; $10 \mathrm{mM}$ of $p$ NP-Glu) (Fig. 5a). The activities of all enzymes were in most cases strongly blocked in the presence of $1.0 \%(\mathrm{w} / \mathrm{v}) 5$-HMF and furfural (approximately 90-95\%). Interestingly, the presence of $0.5 \%$ (w/v) 5-HMF inhibited all enzymes by $50-60 \%$, whereas protein 2 with $p$ NP-Ara showed nearly $100 \%$ inhibition. At the lower dosages $(0.05-0.1 \% \mathrm{w} / \mathrm{v}), 5$-HMF inhibited all enzymes by $10-40 \%$ (Fig. $5 \mathrm{a}$ ). Next to that, the presence of $0.5 \%(\mathrm{w} / \mathrm{v})$ furfural resulted in an inhibitory effect of $50 \%$ to proteins 1 and 5, but in one close to $100 \%$ for protein 2 (with $p \mathrm{NP}-\mathrm{Xyl}$ and $p \mathrm{NP}-\mathrm{Ara}$ ) (Fig. 5a). Notably, low levels (0.05$0.1 \% \mathrm{w} / \mathrm{v}$ ) of furfural showed about $10-70 \%$ inhibition.

The efficiency of degradation of raw wheat straw by the four enzymes was determined by measuring the total sugars released. The data suggested that the $24 \mathrm{~h}$ treatment showed higher hydrolysis effect for all enzymes (proteins 1, 2, 5 and 6) when compared with the $12 \mathrm{~h}$ treatment (Fig. 5b). The amount of total sugars was higher in the presence of protein $6(0.44 \mathrm{mg} / \mathrm{ml})$ when compared with the other three proteins. Moreover, the addition of protein 1 yielded $0.35 \mathrm{mg} / \mathrm{ml}$ of total sugar. Interestingly, addition of all enzymes together (mixed) increased the $24 \mathrm{~h}$ yield up to $0.55 \mathrm{mg} / \mathrm{ml}$ (Fig. $5 \mathrm{~b}$ ).

\section{Enzyme activities in the presence of ions}

To examine the effects of ions (including $\mathrm{NaCl}$ ) on the four selected enzymes (Table 2), activity tests under different ionic regimes were carried out with the appropriate substrates. In the presence of all $\mathrm{MgCl}_{2}, \mathrm{MnCl}_{2}$ and $\mathrm{NaCl}$ levels, the enzymes encoded by genes 1,2 and 6 showed increased activities, of between 10 and $25 \%$ of the control (without ions). Protein 2, on $p$ NP-Ara, showed significantly increased $(P<0.05)$ activity $(50 \%)$ in the presence of $5 \mathrm{mM}$ of $\mathrm{Mg}^{2+}$, as compared to the controls without ions, and almost $80 \%$ elevated activity with $200 \mathrm{mM}$ of $\mathrm{NaCl}$. Finally, protein 6 showed increased $\alpha$-glucosidase activity (50\%) in the presence of $200 \mathrm{mM}$ of $\mathrm{NaCl}$ when compared to the controls without $\mathrm{NaCl}$. In fact, all additives, except $5 \mathrm{mM}$ of $\mathrm{Mg}^{2+}$, significantly increased this enzymatic activity. Strikingly, the protein $5 \alpha$-glucosidase activity decreased in the presence of all additives; the activity was significantly lowered upon addition of both $5 \mathrm{mM}$ of $\mathrm{Mg}^{2+}$ and $2000 \mathrm{mM}$ $\mathrm{NaCl}(\mathrm{p}<0.05)$.

\section{Analysis of the sequences of proteins 5 and 6 Evidence for a new a-glucosidase encoded by gene 5}

Analyses of protein 5, using BLAST-P, multiple sequence alignment and subsequent tree building with the first 19

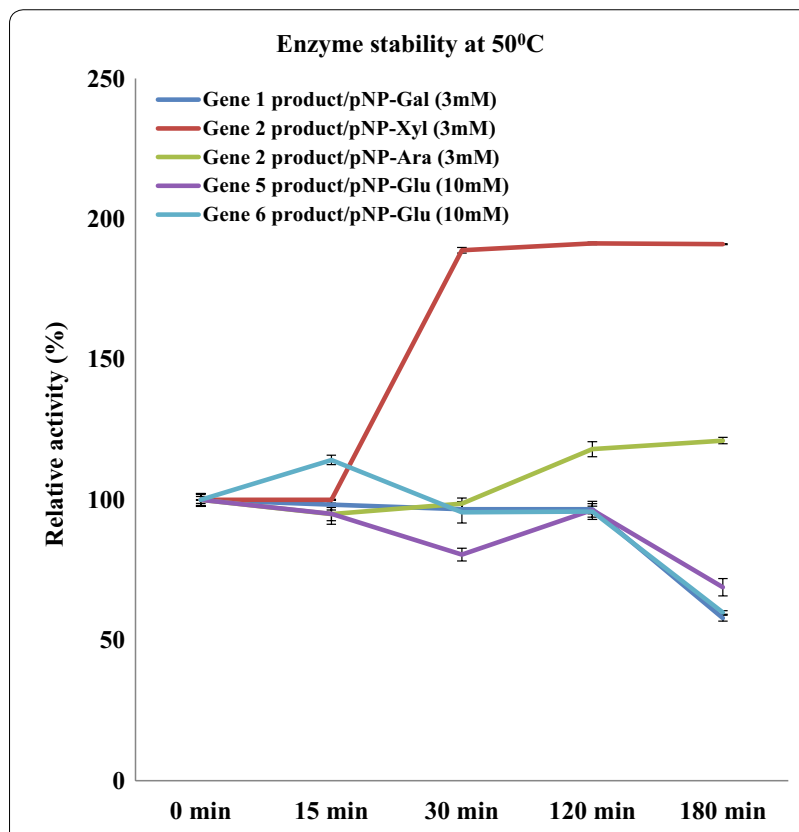

Fig. 4 The effect of temperature on enzyme stabilities. Explanation: activities of proteins 1,5 and 6 were stable up to $120 \mathrm{~min}\left(\right.$ at $50^{\circ} \mathrm{C}$ ): protein 2 showed increased activity up to $180 \mathrm{~min}$ at $50^{\circ} \mathrm{C}$ 


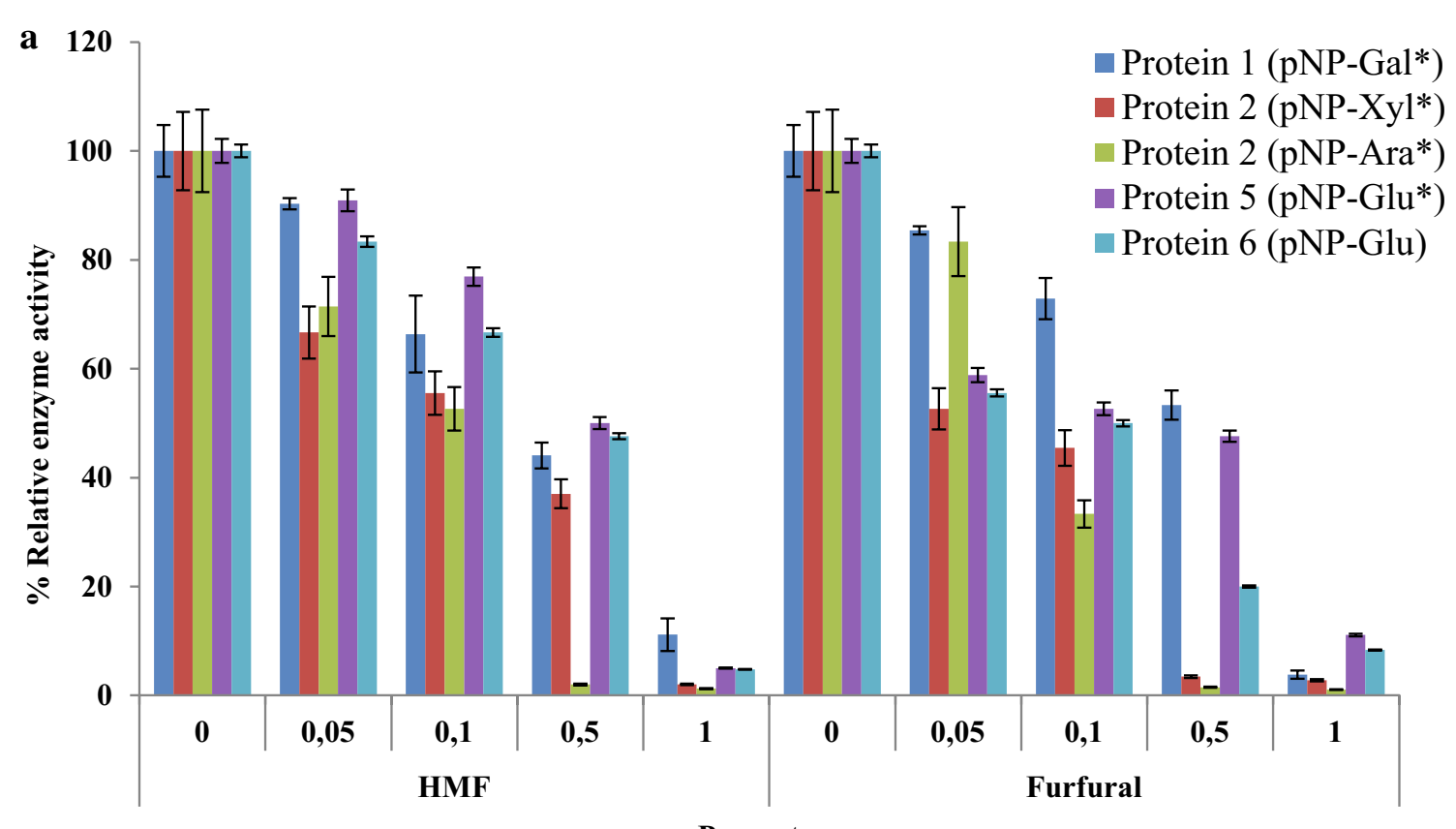

Percentage

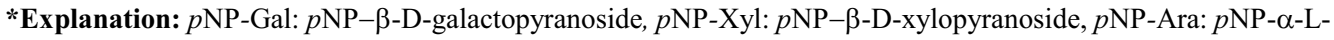
arabinopyranoside and $p$ NP-Glu: $p$ NP- $\alpha$-D-glucopyranoside

b

Enzyme hydrolysis- Raw wheat straw

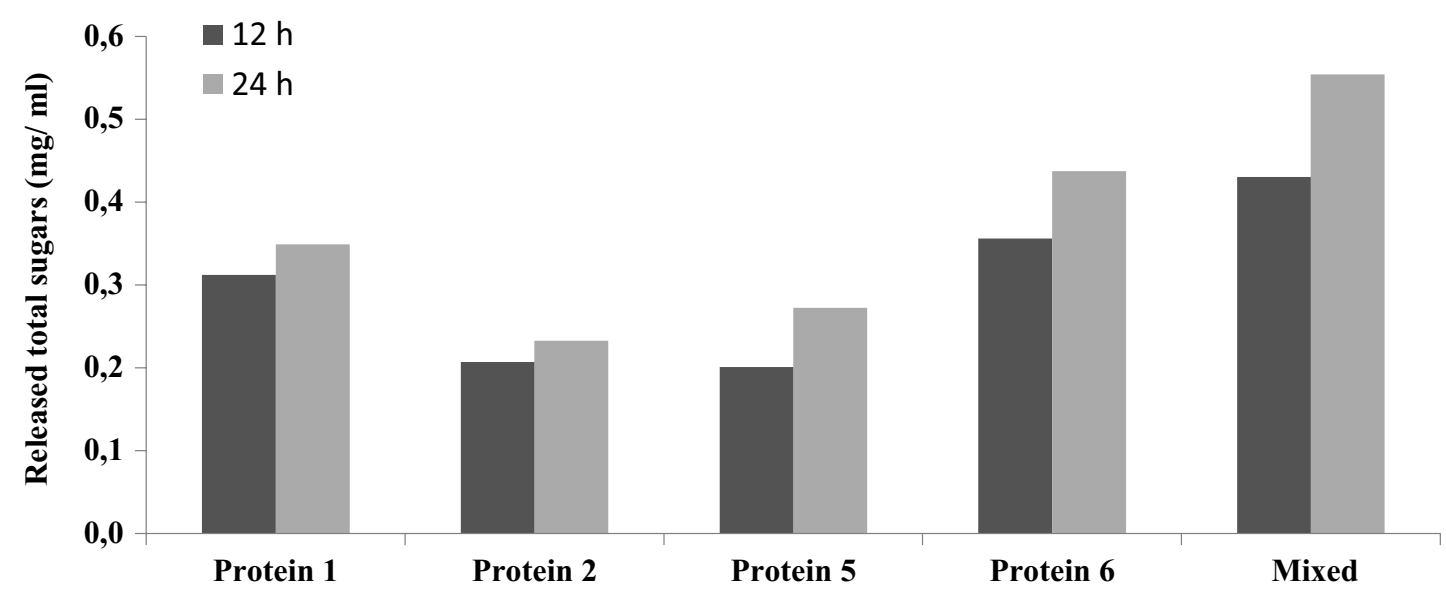

Fig. 5 Relative activities of proteins 1,2,5 and 6. a. different concentrations (zero to 1.0\% (w/v)) of furfural and 5-hydroxymethylfurfural (5-HMF); b. effect of lignocellulosic polysaccharide hydrolysis (raw wheat straw)

matches, revealed between 81 and $92 \%$ identity of the protein with proteins defined as 'diguanylate cyclase' from, respectively, Kluyvera cryocrescens and Enterobacter cloacae (Additional file 1: Figure S1). Further characterization of the domains of protein 5 using Pfam revealed a quite complex domain architecture. Two putative conserved domains were identified, denoted as 'HAMP' and 'GGDEF' (Fig. 6). The HAMP domain has been described as a signaling mediator, being mostly found in histidine kinases, adenyl cyclases, methyl-accepting proteins and phosphatases [23]. HAMP domains consist of 16-residue amphiphilic helices that are often part of a twocomponent signal transduction pathway [24]. They can be found in association with other domains, such as the GGDEF and EAL domains. Remarkably, gene 5 is here described as a gene encoding a glycoside hydrolase family GH53 protein (analysis by the CAZymes analysis toolkit (CAT) server), with predicted endo- $\beta$-1, 4-galactanase 
Table 2 Effects of metal ions and $\mathrm{NaCl}$ on the enzymatic activities of recombinant enzymes (each treatment had three

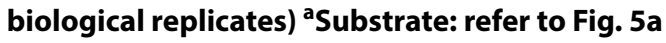

\begin{tabular}{|c|c|c|c|c|c|c|c|c|}
\hline \multirow{3}{*}{$\begin{array}{l}\text { Enzymes } \\
\text { (product of:) }\end{array}$} & \multirow[t]{3}{*}{ Substrate $^{a}$} & \multirow[t]{3}{*}{ No additive } & \multicolumn{6}{|c|}{ Relative activities (\%) } \\
\hline & & & \multicolumn{2}{|l|}{$\mathrm{MgCl}_{2}$} & \multicolumn{2}{|l|}{$\mathrm{MnCl}_{2}$} & \multicolumn{2}{|l|}{$\mathrm{NaCl}$} \\
\hline & & & $5 \mathrm{mM}$ & $20 \mathrm{mM}$ & $5 \mathrm{mM}$ & $20 \mathrm{mM}$ & $200 \mathrm{mM}$ & $2000 \mathrm{mM}$ \\
\hline Gene 1 & pNP-Gal & $100 \pm 1.8$ & $113.1 \pm 9.1$ & $114.1 \pm 9.6$ & $97.7 \pm 6.5$ & $95.5 \pm 9.2$ & $91.7 \pm 3.5$ & $90.9 \pm 3.6$ \\
\hline Gene 2 & pNP-Xyl & $100 \pm 4.9$ & $124.5 \pm 0.7$ & $129.9 \pm 4.9$ & $108.6 \pm 4.4$ & $105.0 \pm 3.2$ & $112.4 \pm 12.4$ & $118.6 \pm 9.3$ \\
\hline Gene 2 & pNP-Ara & $100 \pm 17.6$ & $150.5 \pm 19.4$ & $106.4 \pm 26.0$ & $135.5 \pm 7.6$ & $81.6 \pm 1.2$ & $183.9 \pm 53.1$ & $75.1 \pm 1.9$ \\
\hline Gene 5 & pNP-Glu & $100 \pm 2.7$ & $85.4 \pm 3.4$ & $94.0 \pm 6.3$ & $95.6 \pm 2.3$ & $88.7 \pm 1.0$ & $102.7 \pm 3.8$ & $59.9 \pm 2.4$ \\
\hline Gene 6 & pNP-Glu & $100 \pm 4.1$ & $105.5 \pm 1.4$ & $112.8 \pm 5.5$ & $92.8 \pm 2.3$ & $111.1 \pm 1.0$ & $159.5 \pm 3.6$ & $119.3 \pm 5.1$ \\
\hline
\end{tabular}

activity based on the (catalytic) GGDEF domain. Therefore, we here posit that protein 5 is a GGDEF family protein, which is part of a signal-responsive system (given its HAMP domain), with $\alpha$-glucosidase activity as shown with $p$ NP- $\alpha$-D-glucopyranoside.

Furthermore, we analyzed the protein 5 amino acid sequence based on domain architecture and revealed potential "GDSL" motifs (by CDART); the presence of such a GDSL motif may indicate the potential for multiple functional properties, such as broad substrate specificity, given its active site flexibility. Due to this, multiple activities, such as lipase and esterase activities, could be present, which are of use in hydrolysis processes of biological interest [25]. Further 3D modeling of protein 5 (Fig. 8a) indicated the presence of hypothetical ligands of both the GGDEF and GDSL domains that may allow binding of a particular substrate, supporting a catalytic mechanism.

\section{Evidence for a new a-glucosidase encoded by gene 6}

In the case of the gene 6 product, a BLAST-P search initially showed high similarity of it to typical porin-like proteins, with up to $97 \%$ identity. Specifically, the predicted protein clustered with porins from the genera Martelella endophytica (80\%) and Devosia sp. root635 (97\%), which are both Alphaproteobacteria from the order Rhizobiales (Additional file 2: Figure S2). Connected to this, the characterization of the different domains in the predicted protein yielded a match with transmembrane channelforming proteins of the major intrinsic protein (MIP) family from Hyphomonas johnsonii and Brevundimonas diminuta. The predicted protein 6 was found to contain the characteristic Asn-Pro-Ala (denoted as NPA) signature motif located at the segment interface between helices M3 and M7 in residues 103-105 (Fig. 7, in yellow). In our previous study, the source fosmid clone NT18-17 produced proteins with $\alpha$-glucosidase activity. Here, the product of the cloned gene 6 showed 100\% increased $\alpha$-glucosidase activity at $\mathrm{pH} 10.0$ (Fig. 3j). Finally, protein 6 was analyzed with respect to domain architecture.
A potential "GDSL" motif was also found by the CDART software, the potential function, and characterization of this motif being as above. Using 3D modeling (Fig. 8b), hypothetical substrate-binding ligands were identified, supporting the tenet that a catalytic site is present in this presumed transmembrane protein.

\section{Discussion}

Metagenomics constitutes a true 'breakthrough tool' that allows to examine natural and manipulated microbiomes for the presence of genes for novel enzymes that may fuel biomedical and industrial applications [26]. In a previous study involving two wheat straw-degrading microbial consortia, we identified two genes encoding proteins with putative thermo-alkaliphilic activities [14]. With respect to activity ( $\beta$-galactosidase and $\beta$-xylosidase), these were stable at alkaline $\mathrm{pH}$ and elevated temperature. Hence, they may have interesting potential applications in the process of enzyme-assisted pulp bleaching [14]. In the current study, we further mined our fosmids that were predicted to encode such GHases. Eight thus selected genes were cloned into two $E$. coli host strains, BL21(DE3) and Origami2 (DE3) pLysS, and gene expression was examined. Strain BL21(DE3) is useful for gene expression studies from a T7-type promoter on the vector. In our study, BL21(DE3) cell growth was arrested, possibly as a result of the emergence of inhibitory compounds, i.e., the intended proteins, in the culture. In the case of E. coli Origami2 (DE3) pLysS, the T7 lysozyme produced suppresses the basal expression of T7 RNA polymerase prior to induction. Thus, we found $E$. coli Origami2 (DE3) pLysS to produce more proteins in the soluble fractions than BL21(DE3), giving rise to five (genes 1, 2, 3, 5 and 6) measurable enzyme activities. In our previous work [14], fosmid clone 10BT extracts showed activity with multiple substrates and also light $(14.8 \%) \quad \beta$-xylosidase activity. There was no detectable $\alpha$-glucosidase activity. Interestingly, protein 5 (originating from clone 10BT) showed $\alpha$-glucosidase activity from the strong inducible promoter of the vector. Thus, 


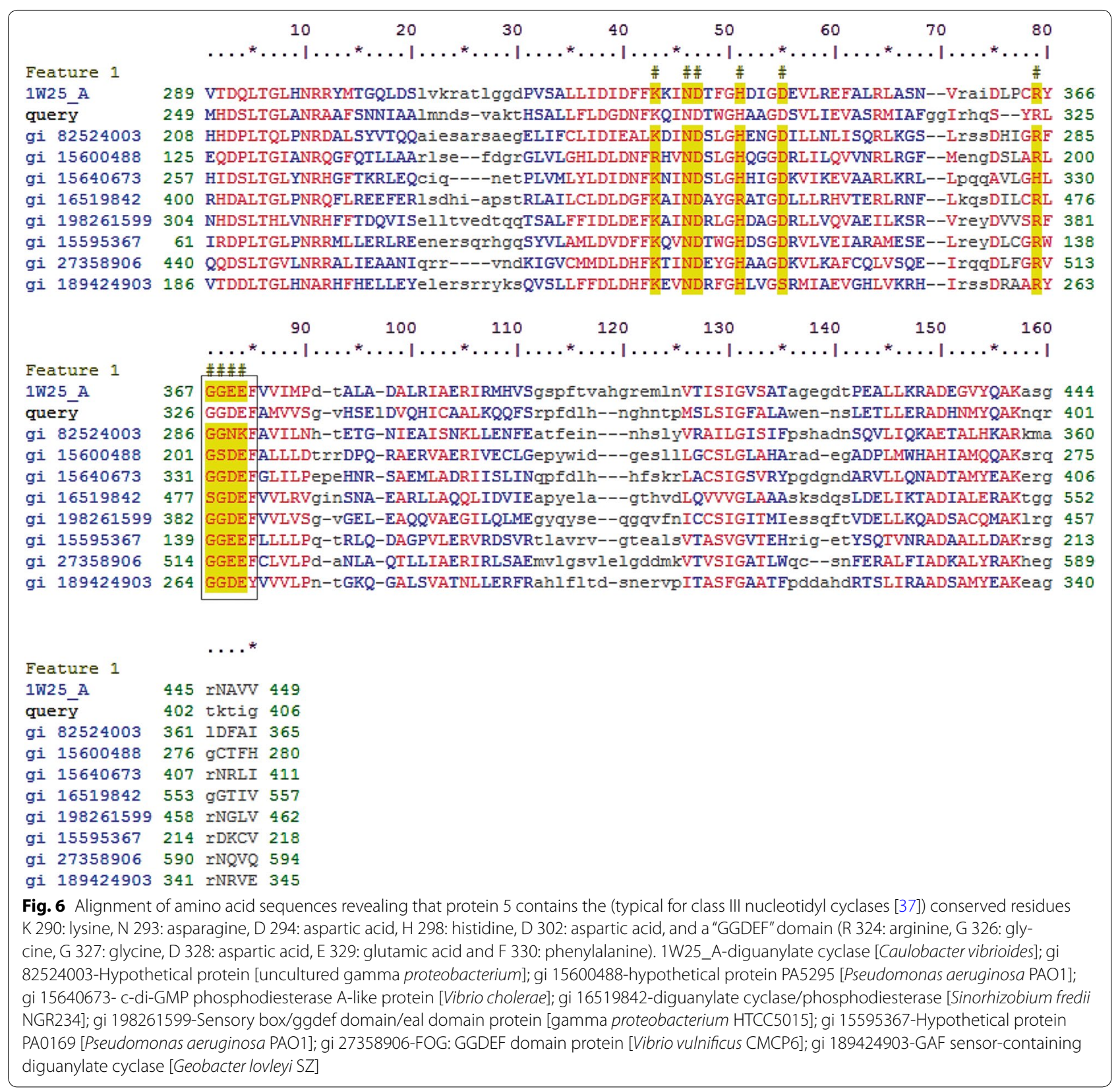

presumably the native promoter of this gene did not allow for expression under such conditions. Concerning genes 7 and 8, no activity was found with any of the test substrates, of which we ignore the cause. However, problems of instability and/or aggregation (under the prevailing conditions of osmolarity, $\mathrm{pH}$, redox potential, cofactors) may have played key roles.

Based on the initial screening, we thus considered the selected five genes for further study of their products. Among these, proteins 2 and 3 were similar in activity and size. With reference to our previous study, here we selected gene 2 instead of gene 3 (from fosmid clone
T5-5) based on the high thermo-alkaliphilic activity with $p$ NP-Xyl, whereas the gene 3 mother fosmid clone T4-1 had shown only slight activity against $p$ NP-Xyl [14].

\section{Protein 1}

With respect to the identification of protein 1 as an EC. 3.2.1.23 (GH2), several new $\beta$-galactosidase family - $\mathrm{GH} 2$ enzymes have recently been discovered and characterized [27-29]. Specifically, a purified ( $\beta$-galactosidase) family -GH2 enzyme, denoted BglA, from Arthrobacter psychrolactophilus F2 showed maximal enzymatic activity (alkaliphilic) at $\mathrm{pH} 8.0 / 10{ }^{\circ} \mathrm{C}(33.3 \mathrm{U} / \mathrm{mg})$. Such 


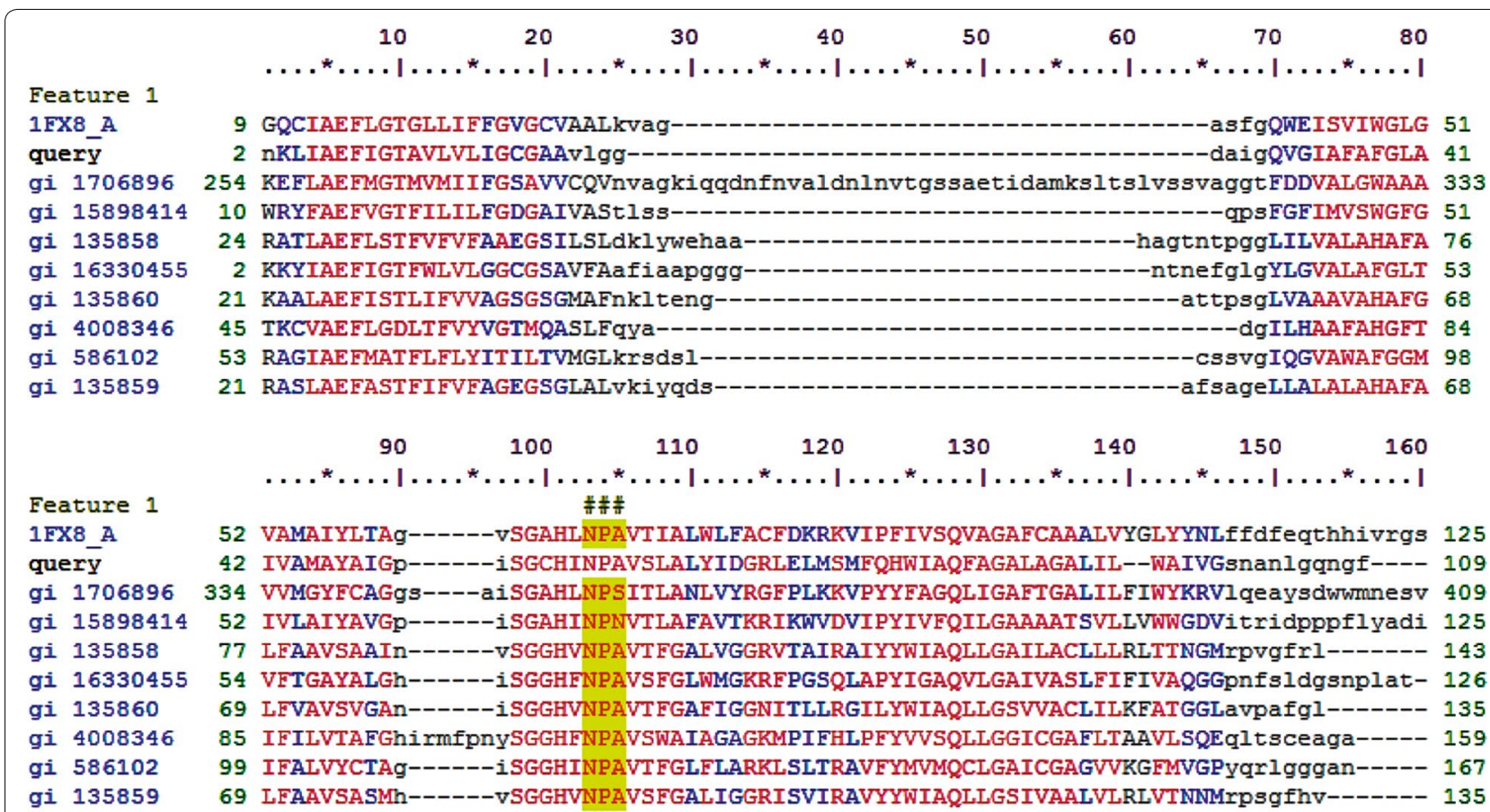

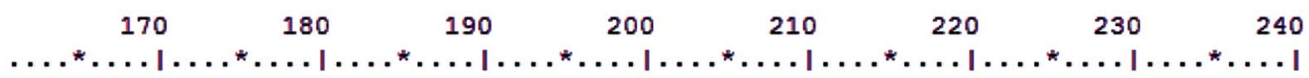

Feature 1

1 FX8 A query

126 ves------------------------vdlagtfstypnphinfVQAFAVEMVITAILMGLILALTDdgngv---prgpLAP 180

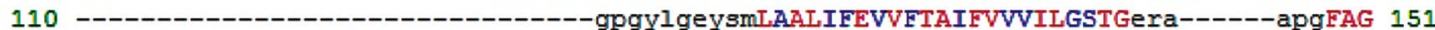

gi 1706896410 ----------------------------agmfcvfpkpY1ssGRQFFSE FLCGAMLQAGTFALTDpytc-----1ssdVFP 457

gi 15898414126 gaafftqYpepgfwpqywpksylpnvssagilysqvnqifplWKGAFAEALMTFLLLLIVVAVTDpdspf---ysqsLAP 202

gi 135858144 -----------------------------------asgvgaVNGLVLEIILTFGLVYVVYSTLIdpkrg---31giIAP 184 gi 16330455127 --------_---_---_----------ngfgdhspqgygfL_AALLIEFVLTFIFLIVILGVTDkta-------pagFAP 171

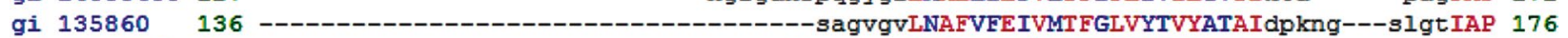
gi 4008346160 -------------------------------------tllspgsqwWQGLIAETVVTFFLVHTILITAAdtd-------tVtLAP 200 gi 586102168 -----------------------------------vvnpgytkGDGLGAEIIGTFVLVYTVFSATDakrnardshvpiLAP 213

gi 135859136 -----------------------------------spgvgvGHMFILEVVMTFGLMYTVYGTAIdpkrg---avsYIAP 176

Feature 1 1FX8 A query gi 1706896 gi 15898414 gi 135858

gi 16330455

gi 135860

gi 4008346

gi 586102

gi 135859

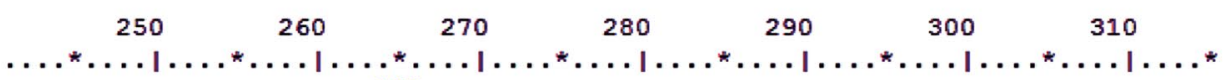

\section{\#\#\#}

181 LLIGLLIAVIGasm-gplTGFAMNPARDFGPKVFawlagwgnvaftggrdipYFLVPLFGPIVGAIVGAFAYRKL 254 152 LAIGLTLVAIHIVg-iqvTGVSVNPARSFGPAILvggd-----------alaQLWLFIVAPLAGGALGGLLYRLr 214 458 LMMFILIFIINasm-ayqTGTAMNLARDLGPRLAl yavgfdhk-mlwvhhhhFFWVPMVGPFIGALMGGLVYDVC 530 203 WAIGIGYVMPFllfeaqlTGGMINEARSWGPMIAlylfgyrt--gafnfrgeYFYVYGIPDFIGGILGALFWDHV 275 185 LAIGLIVGANI $1 \mathrm{vg-gpfSGASMNPARAFGPALVgWr------------whDHWIYWVGPFIGSALAALIYEYM} 245$ 172 AAIGLALTLIHIis-ipiTNTSVNPARSTGVALFcgnp-----------aligQLWLFWLAPIAGALLAGFVYHNV 235 177 IAIGFIVGANIlag-gafSGASMNPAVAFGPAVVswt-------------wtNHWVYWAGPLVGGGIAGLIYEVF 237 201 LAIGLTLSIDIlst-gsiTGASMNPARSLGPSIIgsifatq----ktsfYwnNHYIYWAGPLLGSTIALCIYKLF 270 214 LPIGFAVFLVHlat-ipiTGTGINPARSLGAAIIYnde----------hawnDHWIFWVGPMIGAALAAIYHQII 277 177 L.AIGLIVGANIlvg-gpfDGACMNPAL.AFGPSLVgwq-------------whQHWIFWVGPLLGAALAALVYEYA 237

Fig. 7 Alignment of protein 6 amino acid sequences showed two highly conserved NPA motifs (asparagine-proline-alanine; highlighted yellow). 1FX8_A-Membrane protein [Escherichia coli]; gi 1706896-Glycerol uptake/efflux facilitator protein [Saccharomyces cerevisiae S288C]; gi 15898414-transposon ISC1229 Orf1 [Sulfolobus solfataricus P2]; gi 135858-Aquaporin TIP3-1 [Arabidopsis thaliana]; gi 16330455-Aquaporin Z [Synechocystis sp. PCC 6803]; gi 135860-Aquaporin TIP1-1 [Arabidopsis thaliana]; gi 4008346-Major intrinsic protein [Caenorhabditis elegans]; gi 586102-Membrane protein [Solanum lycopersicum]; gi 135859-Aquaporin TIP-type alpha [Phaseolus vulgaris]

$\beta$-galactosidases are widely used in the food industry given their capabilities to hydrolyze lactose at extreme (low or high) temperatures, and to produce glucose and galactose. Remarkably, our gene 1 encoded protein showed increased enzymatic activity at raised temperature and similar $\mathrm{pH}$ when compared to the BglA 


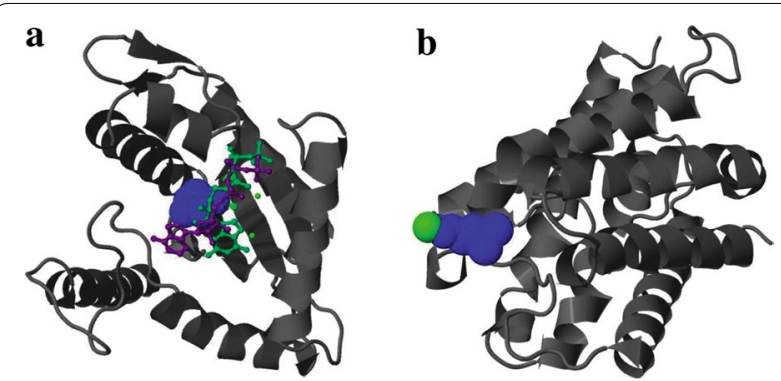

Fig. 8 Three-dimensional (3D) models of a. protein 5 and b. protein 6. Background helices shown in gray, Active sites shown in blue, Hypothetical ligands shown in magenta and green

enzyme, with increased $p$-nitrophenol release (58.7 U/ mg; Table 3). Moreover, protein 1 showed a lower $K_{\mathrm{m}}$ and slightly increased $V_{\max }$ as compared to those of the aforementioned $A$. psychrolactophilus enzyme, as well as a and Lactobacillus sakei Lb790 enzyme [27, 29]. Therefore, protein 1 shows promising hydrolytic activity, which may be of direct relevance to industrial processes.

\section{Protein 2}

Gene 2 was annotated as a gene encoding a protein with $\beta$-xylosidase $/ \alpha$-arabinosidase activity belonging to CAZy family GH3 (EC. 3.2.1.37). As shown in Table 3, the enzyme had raised activities on $p \mathrm{NP}-\mathrm{Xyl}$ and $p \mathrm{NP}$-Ara, with optimum $\mathrm{pH}$ values of 9.0 (and 6.0) at temperatures of 50 and $40{ }^{\circ} \mathrm{C}$. This was superior as compared to the previously reported enzymes Rubgx1, GH43 (several) and XynB5. Specifically, the Rubgx1 (GH3 family) enzyme
( $\beta$-glucosidase $/ \beta$-xylosidase activities; optima at $\mathrm{pH}$ 6.0 and $50{ }^{\circ} \mathrm{C}$ ) [30], the GH43 family one ( $\beta$-xylosidase/ $\alpha$-arabinosidase; optima at $\mathrm{pH} 7.0$ and $40{ }^{\circ} \mathrm{C}$ ) [31] and, finally, XynB5 ( $\beta$-glucosidase/ $\beta$-xylosidase $/ \alpha$ arabinosidase; optimum $\mathrm{pH} 6.0$ and temperature $50{ }^{\circ} \mathrm{C}$ ) had lower activities than protein 2 [32]. In addition, protein 2 revealed high kinetic parameters, such as $V_{\max }$ (666.6 and $102 \mathrm{U} / \mathrm{mg}$ ), than a previously-characterized bifunctional ( $\beta$-xylosidase/ $\alpha$-arabinosidase) enzyme [31]. In another study, we recently characterized GH43 family enzyme XylM1989 with $\beta$-xylosidase/ $\alpha$-arabinosidase activity and showed $V_{\max }$ values of $285.71 / 78.12 \mathrm{U} / \mathrm{mg}$, respectively (unpublished data). Also, protein 2 progressively showed higher enzyme activity (with the corresponding substrates) with increasing $\mathrm{pH}$. Such changes in $\mathrm{pH}$ will alter the attractions between groups in the side chains of the protein, potentially modifying the protein domain shape. Moreover, the binding of substrate to the active site may be modulated and/or it cannot undergo catalysis.

As indicated above, protein 2 was similar to the GH3 family proteins Rubgx1 (81.4 kDa) and XynB5 (95 kDa, from Caulobacter crescentus) [30, 32]. Its $p \mathrm{NP}-\mathrm{Xyl}$ and $p$ NP-Ara dual activity may have been due to two distinct catalytic properties in the same polypeptide chain, usually catalyzing two consecutive reactions [33]. Dual- or even multi-functional properties are common in proteins of the GH3 (and GH43) family. For instance, the GH3 family protein XynB5 showed rather similar $\quad \beta$-glucosidase $/ \beta$-xylosidase $/ \alpha$-arabinosidase activities [32]. Moreover, GH3 family enzymes include

Table 3 Comparison with enzymes (GH2 and GH3/43) from other studies (reactions with the substrate ONPG and/or PNPG)

\begin{tabular}{|c|c|c|c|c|c|c|c|}
\hline $\begin{array}{l}\text { Enzyme } \\
\text { family }\end{array}$ & Functions & Strain & $\begin{array}{l}\text { Protein } \\
\text { (kDa) }\end{array}$ & $\begin{array}{l}\text { Optimum } \\
\operatorname{Tm}\left({ }^{\circ} \mathrm{C}\right)\end{array}$ & $\begin{array}{l}\text { Optimum } \\
\mathrm{pH}\end{array}$ & $\begin{array}{l}\text { Activity (U/ } \\
\text { mg) }\end{array}$ & References \\
\hline $\mathrm{GH} 2$ & $\beta$-Galactosidase & $\begin{array}{l}\text { Arthrobacter psychrolact- } \\
\text { ophilus F2 }\end{array}$ & 130 & 10 & 8 & 33.3 & Nakagawa et al. [27] \\
\hline $\mathrm{GH} 2$ & $\beta$-Galactosidase & Arthrobacter sp. $20 B$ & 113.7 & 25 & $6-8$ & 0.84 & Bialkowska et al. [56] \\
\hline $\mathrm{GH} 2$ & $\beta$-Galactosidase & Arthrobacter SB & 114 & 18 & 7 & 26.9 & Coker and Brenchley [57] \\
\hline $\mathrm{GH} 2$ & $\beta$-Galactosidase & Flavobacterium sp. 4214 & 114.3 & 42 & 7.5 & - & Sørensen et al. [58] \\
\hline $\mathrm{GH} 2$ & $\beta$-Galactosidase & Halomonas sp. S62 & 63 & 45 & 7 & - & Wang et al. [59] \\
\hline $\mathrm{GH} 2$ & $\beta$-Galactosidase & Enterobacter hormaechei & 120 & 50 & 8 & 58.7 & This study \\
\hline $\mathrm{GH} 3$ & $\begin{array}{l}\text { Dual function ( } \beta \text {-xylosidase/a- } \\
\text { arabinofuranosidase) }\end{array}$ & $\begin{array}{c}\text { Rumen/Parabacteroides } \\
\text { distasonis ATCC } 8503\end{array}$ & 80 & 50 & 6 & 29.5 & Zhou et al. [30] \\
\hline $\mathrm{GH} 43$ & $\begin{array}{l}\text { Dual function ( } \beta \text {-xylosidase/a- } \\
\text { arabinofuranosidase) }\end{array}$ & Rumen/Prevotella bryantii & 45 & 40 & 7 & $36.3 / 14.2$ & Zhou et al. [31] \\
\hline GH3-BglX & $\begin{array}{l}\text { Dual function ( } \beta \text {-xylosidase/a- } \\
\text { arabinofuranosidase) }\end{array}$ & C. crescentus & 90 & $60 / 50$ & 6 & $4.3 / 3.0$ & Justo et al. [32] \\
\hline $\mathrm{GH} 3$ & $\begin{array}{l}\text { Dual function ( } \beta \text {-xylosidase/a- } \\
\text { arabinofuranosidase) }\end{array}$ & Enterobacter mori & 80 & $50 / 40$ & 9 and 6 & $122.11 / 16.6$ & This study \\
\hline
\end{tabular}


$\beta$-xylosidases (EC 3.2.1.37) and $\alpha$-arabinosidases (EC 3.2.1.55). Whereas the aforementioned enzymes Rubgx1 and XynB5 showed ( $\beta$-xylosidase) activities with optimum $\mathrm{pH}$ and temperature of 6.0 and $50{ }^{\circ} \mathrm{C}$, respectively, protein 2 showed maximal activity at $\mathrm{pH} 9.0$ and $50{ }^{\circ} \mathrm{C}$ (122.11 U/mg) (Fig. 3d). This preference for alkaline instead of slightly acidic conditions is likely connected to amino acid substitutions that we have-as yet-not addressed. The mechanisms by which an enzyme's catalytic properties may be affected were beyond the scope of the current study [34].

\section{Protein 5}

Interestingly, protein 5 showed $\alpha$-glucosidase activity, whereas no such activity was detected from its mother fosmid clone 10BT [14]. Fosmid clone 10BT had shown activity in the presence of multiple substrates, revealing some activity with $p$ NP-Xyl. Thus, expression of the $\alpha$-glucosidase encoding gene may have been repressed at the genomic level, becoming expressed from the inducible promoter of the expression system of the used vector. Protein 5 clearly belongs to the "GGDEF" domain protein family $[35,36]$. This domain was first identified in a response regulator involved in cell differentiation in C. crescentus [37]. It was also observed in Salmonella enterica enzymes involved in cellulose biosynthesis and biofilm formation [38]. For more than 20 years, all GGDEF domain enzymes have been classed as diguanylate cyclases and/or phosphodiesterases [39]. The former enzymes produce cyclic di-GMP (cdiG), a messenger that regulates the key bacterial lifestyle transition from a motile to a sessile, biofilm-forming, state [40]. However, most bacteria are known to possess large numbers of genes that encode a range of GGDEF domain proteins [38], allowing functional diversity across them. The function of most GGDEF domain containing proteins has not yet been experimentally proven [41]. Surprisingly, the GGDEF domain family protein 5 revealed $\alpha$-glucosidase activity (in the context of (hemi)cellulose degradation), with a $100 \%$ raised activity at $\mathrm{pH} 10.0(102.54 \mathrm{U} / \mathrm{mg})$ as compared to $\mathrm{pH}$ 7.0. At $\mathrm{pH} 10$, the large $\mathrm{OH}^{-}$oversupply may have caused a change in the shape and/or charge of the enzyme's active site, spurring activity. Further detailed structural studies could reveal the dynamics of such glycoside hydrolase activities at varying $\mathrm{pH}$ values in the lignocellulose degradation processes. Also, protein 5 was found to have a different motif, of the "GDSL" class by CDART prediction.

\section{Protein 6}

Remarkably, protein 6 was found to possess two different conserved motifs, NPA and GDSL. The NPA motif is a key structural feature of proteins that plays crucial roles as water channels across membranes, supporting membrane localization of the protein. Surprisingly, protein 6 also belongs to the GDSL hydrolase family (encompassing esterases/lipases), not sharing sequence homology with any of the CAZy database glycosyl hydrolases. GDSL motif enzymes constitute a rather new group of proteins, with characteristics that have not yet been precisely described [42]. Furthermore, a subgroup of this GDSL family was categorized as a so-called SGNH hydrolase, and our protein 6 belongs to this subgroup. The SGNH family of hydrolytic enzymes has a wide range of catalytic functions, such as lipase, protease, carbohydrate esterase, (thio)esterase, arylesterase and acyltransferase activities [43]. All GDSL hydrolase family enzymes were found to have flexible substrate-binding and/or active sites [43]. Indeed, the Koshland inducedfit theory indicates that the active sites of enzymes may become modified in the presence of substrates, involving structural and catalytic site modifications [44]. The active and/or binding sites of protein 6 are presumably flexible if they are to follow the induced-fit theory. For instance, the newly-identified carbohydrate esterase family 3 (CE3) gene axe 2 product (acetyl xylan esterase), which has a GDSL motif, removes acetyl groups from the hemicellulose polymer xylan [45]. Such activity, i.e. carbohydrate esterase, likely gives protein 6 the capability to hydrolyze substituents on the xylan backbone, supporting its ability to competently degrade hemicellulose [46]. Indeed, protein 6 (and 5), based on an SGNH-type hydrolase, may exhibit the specific $\alpha$-glucosidase activity in (hemi)cellulose degradation.

In recent years, several enzyme cocktails have been proposed that can enhance plant biomass degradation rates [47]. Such cocktails were produced from several sources, including the producer organisms Trichoderma reesei, Thermobifida fusca and Clostridium thermocellum. The degradation of lignocellulose requires the intensive action of multiple enzymes. This is due to the structural aspects that are typical for the substrate, i.e., its high molecular weight and the association of hemicellulose with cellulose and lignin. The required hemicellulases need to hydrolyze glycosidic bonds. In many habitats, the degradation process is rather slow because of the poor substrate accessibility, inhibitors (5-HMF and furfural), and untimely presence of efficient enzymes. However, in industrial processes, such enzyme availabilities can be steered $[48,49]$. The inhibitory by-products 5 -HMF and furfural are released during lignocellulose degradation, and constitute a major inhibitors of subsequent fermentation [50, 51]. However, the amount of 5-HMF and furfural in plant biomass hydrolysates is strongly linked to the pretreatment methods and the source of the plant biomass. In 
this line, the levels of 5-HMF and furfural in corn, poplar and pine were 0.017 and $0.022 \%(\mathrm{w} / \mathrm{v})$, respectively [52]. Interestingly, the four enzymes (proteins 1, 2, 5 and 6) showed $50-80 \%$ tolerance to $0.1 \%$ 5-HMF, and about $40-50 \%$ tolerance to $0.5 \%(\mathrm{w} / \mathrm{v})$. In addition, all enzymes also revealed tolerance $(30-72 \%)$ to furfural. Remarkably, protein 5 (with $\alpha$-glucosidase activity) revealed $50 \%$ activity at $0.5 \%$ of 5 -HMF and furfural. Therefore, we posit that such inhibitor-tolerant galactosidases and glucosidases have great interest in food and biorefinery industries. Because of this strong tolerance, our enzymes may work better than other ones in the presence of certain levels of inhibitors. As of now, no previous studies reported 5-HMF- and furfural-tolerant $\beta$-galactosidases and $\alpha$-glucosidases.

The four (thermo-stable) enzymes described here may pave the way towards improved (hemi) cellulolytic action of existing enzyme cocktails. Using the his-tags, the enzymes, provided they are sufficiently stable, can be easily recovered from the treatment process and re-used in continuous applications, allowing alkaline and enhanced temperature conditions [53]. The heredetected activity of our enzymes (specifically proteins 1 and 2) under thermo-alkaliphilic conditions thus indicates their usefulness for plant biomass degradation, spurring the production of glucose and xylose/arabinose from (hemi)cellulosic material and also for pulp bleaching processes. Moreover, thermo-stable enzymes like the ones reported here are often specific for activity on particular bonds and therefore offer promise for specific industrial purposes $[54,55]$. Several amylases and cellulases are already in use in industries, including enzymes with wide $\mathrm{pH}$ range [4.0-10.0] and high thermo-tolerance. They are clearly useful under conditions that restrict microbial growth. Furthermore, enzymes with optimized properties, such as enhanced thermal and alkali tolerance, and an ability to function without additives, recently improved several industrial applications $[51,52]$. In a subsequent study, we will characterize the role of the novel enzymes as modulators of the degradation of hemicellulose compounds.

\section{Additional files}

Additional file 1: Figure S1. Protein 5 Blast-P multiple sequence alignment.Additional file 2: Figure S2. Protein 6 Blast-P multiple sequence alignment.

\footnotetext{
Abbreviations

CAZy: carbohydrate-active enzymes database; GHase: glycosyl hydrolases; ORF: open reading frame; $p N P$ : para-nitrophenyl; RAST: Rapid Annotations using Subsystems Technology; $p N P-G a l: p N P-\beta$-D-galactopyranoside; $p N P-X y l$ :

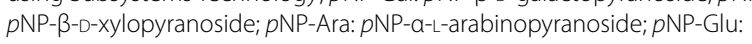

pNP-a-D-glucopyranoside; CBMs: carbohydrate-binding modules; AAs: auxiliary activities; GTs: glycosyl transferases; CEs: carbohydrate esterases.

\section{Authors' contributions}

MM designed, constructed the experiments, and drafted the manuscript. JDVE conceived of the study, and participated in its design and coordination, and helped to draft the manuscript. Both authors read and approved the final manuscript.

\begin{abstract}
Acknowledgements
We thank Maryam Chaib de Mares (for bioinformatics), Diego Javier Jiménez, and Patricia Stevens for the support and suggestions for this study. Further thanks are due to Harald Ruijssenaars and Richard van Kranenburg for scientific support. This work was supported by the Netherlands Ministry of Economic Affairs and the BE-Basic partner organizations (http://www.be-basic.nl).
\end{abstract}

\section{Competing interests}

The authors declare that they have no competing interests.

\section{Publisher's Note}

Springer Nature remains neutral with regard to jurisdictional claims in published maps and institutional affiliations.

Received: 11 December 2016 Accepted: 29 April 2017

Published online: 02 June 2017

\section{References}

1. Sørensen A, Lübeck M, Lübeck PS, Ahring BK. Fungal beta-glucosidases: a bottleneck in industrial use of lignocellulosic materials. Biomolecules. 2013;3:612-31.

2. Gray KA, Zhao L, Emptage M. Bioethanol. Curr Opin Chem Biol. 2006;10:141-6.

3. Dougherty MJ, D'haeseleer P, Hazen TC, Simmons BA, Adams PD, Hadi MZ. Glycoside hydrolases from a targeted compost metagenome, activity-screening and functional characterization. BMC Biotechnol. 2012;12:38

4. Turner P, Mamo G, Karlsson E. Potential and utilization of thermophiles and thermostable enzymes in biorefining. Microb Cell Fact. 2007;6:9.

5. Sims REH, Mabee W, Saddler JN, Taylor M. An overview of second generation biofuel technologies. Bioresour Technol. 2010;101:1570-80.

6. Mohanram S, Amat D, Choudhary J, Arora A, Nain L, Bringezu S, et al. Novel perspectives for evolving enzyme cocktails for lignocellulose hydrolysis in biorefineries. Sustain Chem Process. 2013;1:15 (Springer International Publishing)

7. Gowen CM, Fong SS. Exploring biodiversity for cellulosic biofuel production. Chem Biodivers. 2010;7:1086-97.

8. Bayer EA, Chanzy H, Lamed R, Shoham Y. Cellulose, cellulases and celIulosomes. Curr Opin Struct Biol. 1998;8:548-57.

9. Ljungdahl LG. The cellulase/hemicellulase system of the anaerobic fungus Orpinomyces PC-2 and aspects of its applied use. Ann NY Acad Sci. 2008;1125:308-21.

10. Wongwilaiwalin S, Rattanachomsri U, Laothanachareon T, Eurwilaichitr L, Igarashi Y, Champreda V. Analysis of a thermophilic lignocellulose degrading microbial consortium and multi-species lignocellulolytic enzyme system. Enzyme Microb Technol. 2010;47:283-90.

11. Wang W, Yan L, Cui Z, Gao Y, Wang Y, Jing R. Characterization of a microbial consortium capable of degrading lignocellulose. Bioresour Technol. 2011;102:9321-4.

12. Jiménez DJ, Korenblum E, van Elsas JD. Novel multispecies microbial consortia involved in lignocellulose and 5-hydroxymethylfurfural bioconversion. Appl Microbiol Biotechnol. 2014;98:2789-803.

13. Klein-Marcuschamer D, Oleskowicz-Popiel P, Simmons BA, Blanch HW. The challenge of enzyme cost in the production of lignocellulosic biofuels. Biotechnol Bioeng. 2012;109:1083-7. 
14. Maruthamuthu M, Jiménez DJ, Stevens P, van Elsas JD. A multi-substrate approach for functional metagenomics-based screening for (hemi)cellulases in two wheat straw-degrading microbial consortia unveils novel thermoalkaliphilic enzymes. BMC Genom. 2016;17:86.

15. Altschul SF, Gish W, Miller W, Myers EW, Lipman DJ. Basic local alignment search tool. J Mol Biol. 1990;215:403-10.

16. Finn RD, Coggill P, Eberhardt RY, Eddy SR, Mistry J, Mitchell AL, et al. The Pfam protein families database: towards a more sustainable future. Nucleic Acids Res. 2015;44:D279-85.

17. Papadopoulos JS, Agarwala R. COBALT: constraint-based alignment tool for multiple protein sequences. Bioinformatics. 2007;23:1073-9.

18. Geer LY, Domrachev M, Lipman DJ, Bryant SH. CDART: protein homology by domain architecture. Genome Res. 2002;12:1619-23.

19. Kelley LA, Sternberg MJE. Protein structure prediction on the Web: a case study using the Phyre server. Nat Protoc. 2009;4:363-71.

20. Holm L, Rosenström P. Dali server: conservation mapping in 3D. Nucleic Acids Res. 2010;38:W545-9.

21. Berman HM, Westbrook J, Feng Z, Gilliland G, Bhat TN, Weissig H, et al. The protein data bank. Nucleic Acids Res. 2000;28:235-42.

22. Wulff NA, Carrer H, Pascholati SF. Expression and purification of cellulase Xf818 from Xylella fastidiosa in Escherichia coli. Curr Microbiol. 2006;53:198-203.

23. Aravind $\mathrm{L}$, Ponting CP. The cytoplasmic helical linker domain of receptor histidine kinase and methyl-accepting proteins is common to many prokaryotic signalling proteins. FEMS Microbiol Lett. 1999;176:111-6.

24. Parkinson JS. Signaling mechanisms of HAMP domains in chemoreceptors and sensor kinases. Annu Rev Microbiol. 2010;64:101-22.

25. Messaoudi A, Belguith H, Gram I, Hamida JB. Classification of EC 3.1.1.3 bacterial true lipases using phylogenetic analysis. Afr J Biotechnol. 2010:9:8243-7.

26. Schmidt TM, DeLong EF, Pace NR. Analysis of a marine picoplankton community by $16 \mathrm{~S}$ rRNA gene cloning and sequencing. J Bacteriol. 1991;173:4371-8.

27. Nakagawa T, Fujimoto Y, Ikehata R, Miyaji T, Tomizuka N. Purification and molecular characterization of cold-active beta-galactosidase from Arthrobacter psychrolactophilus strain F2. Appl Microbiol Biotechnol. 2006;72:720-5.

28. Schwab C, Sørensen Kl, Gänzle MG. Heterologous expression of glycoside hydrolase family 2 and $42 \beta$-galactosidases of lactic acid bacteria in Lactococcus lactis. Syst Appl Microbiol. 2010;33:300-7.

29. Iqbal S, Nguyen T-H, Nguyen HA, Nguyen TT, Maischberger T, Kittl R, et al. Characterization of a heterodimeric $\mathrm{GH} 2 \beta$-galactosidase from Lactobacillus sakei Lb790 and formation of prebiotic galacto-oligosaccharides. J Agric Food Chem. 2011;59:3803-11.

30. Zhou J, Bao L, Chang L, Liu Z, You C, Lu H. Beta-xylosidase activity of a $\mathrm{GH} 3$ glucosidase/xylosidase from yak rumen metagenome promotes the enzymatic degradation of hemicellulosic xylans. Lett Appl Microbiol. 2012;54:79-87.

31. Zhou J, Bao L, Chang L, Zhou Y, Lu H. Biochemical and kinetic characterization of GH43 $\beta$-D-xylosidase/a-L-arabinofuranosidase and GH30 a-l-arabinofuranosidase/ $\beta$-D-xylosidase from rumen metagenome. J Ind Microbiol Biotechnol. 2012;39:143-52.

32. Justo PI, Corrêa JM, Maller A, Kadowaki MK, da Conceição-Silva JL, Gandra $\mathrm{RF}$, et al. Analysis of the xynB5 gene encoding a multifunctional GH3BgIX $\beta$-glucosidase- $\beta$-xylosidase- - -arabinosidase member in Caulobacter crescentus. Antonie Van Leeuwenhoek. 2015;108:993-1007.

33. Vrzheshch PV. Steady-state kinetics of bifunctional enzymes. Taking into account kinetic hierarchy of fast and slow catalytic cycles in a generalized model. Biochem. 2007;72:936-43.

34. Tijskens LM, Greiner R, Biekman ES, Konietzny U. Modeling the effect of temperature and $\mathrm{pH}$ on activity of enzymes: the case of phytases. Biotechnol Bioeng. 2001;72:323-30.

35. Cotter PA, Stibitz S. c-di-GMP-mediated regulation of virulence and biofilm formation. Curr Opin Microbiol. 2007;10:17-23.

36. Sinha SC, Sprang SR. Structures, mechanism, regulation and evolution of class III nucleotidyl cyclases. Rev Physiol Biochem Pharmacol. 2006;157:105-40.

37. Hecht $G B$, Newton $A$. Identification of a novel response regulator required for the swarmer-to-stalked-cell transition in Caulobacter crescentus. J Bacteriol. 1995;177:6223-9.
38. García B, Latasa C, Solano C, García-del Portillo F, Gamazo C, Lasa I. Role of the GGDEF protein family in Salmonella cellulose biosynthesis and biofilm formation. Mol Microbiol. 2004:54:264-77.

39. Römling U, Galperin MY, Gomelsky M. Cyclic di-GMP: the first 25 years of a universal bacterial second messenger. Microbiol Mol Biol Rev. 2013;77:152 (American Society for Microbiology (ASM))

40. Hallberg ZF, Wang XC, Wright TA, Nan B, Ad O, Yeo J, et al. Hybrid promiscuous (Hypr) GGDEF enzymes produce cyclic AMP-GMP (3', 3'-cGAMP). Proc Natl Acad Sci. 2016;1 13:1790-5 (National Academy of Sciences)

41. Galperin MY, Nikolskaya AN, Koonin EV. Novel domains of the prokaryotic two-component signal transduction systems. FEMS Microbiol Lett. 2001;203:11-21 (The Oxford University Press).

42. Upton C, Buckley JT. A new family of lipolytic enzymes? Trends Biochem Sci. 1995;20:178-9 (Elsevier Current Trends).

43. Akoh CC, Lee G-C, Liaw Y-C, Huang T-H, Shaw J-F. GDSL family of serine esterases/lipases. Prog Lipid Res. 2004;43:534-52.

44. Koshland DE. Application of a theory of enzyme specificity to protein synthesis. Proc Natl Acad Sci USA. 1958:44:98-104.

45. Alalouf O, Balazs Y, Volkinshtein M, Grimpel Y, Shoham G, Shoham Y. A new family of carbohydrate esterases is represented by a GDSL hydrolase/acetylxylan esterase from Geobacillus stearothermophilus. J Biol Chem. 2011:286:41993-2001.

46. Kabel MA, Yeoman CJ, Han Y, Dodd D, Abbas CA, de Bont JAM, et al. Biochemical characterization and relative expression levels of multiple carbohydrate esterases of the xylanolytic rumen bacterium Prevotella ruminicola 23 grown on an ester-enriched substrate. Appl Environ Microbiol. 2011;77:5671-81 (American Society for Microbiology (ASM)).

47. Cherry JR, Fidantsef AL. Directed evolution of industrial enzymes: an update. Curr Opin Biotechnol. 2003;14:438-43.

48. Subramaniyan S, Prema P. Biotechnology of microbial xylanases: enzymology, molecular biology, and application. Crit Rev Biotechnol. 2002;22:33-64.

49. Beg QK, Kapoor M, Mahajan L, Hoondal GS. Microbial xylanases and their industrial applications: a review. Appl Microbiol Biotechnol. 2001;56:326-38.

50. Garrote G, Domínguez H, Parajó JC. Hydrothermal processing of lignocellulosic materials. Holz als Roh- und Werkst (Springer-Verlag). 1999;57:191-202

51. van der Pol EC, Bakker RR, Baets P, Eggink G. By-products resulting from lignocellulose pretreatment and their inhibitory effect on fermentations for (bio)chemicals and fuels. Appl Microbiol Biotechnol. 2014;98:9579-93.

52. Du B, Sharma LN, Becker C, Chen S-F, Mowery RA, van Walsum GP, et al. Effect of varying feedstock-pretreatment chemistry combinations on the formation and accumulation of potentially inhibitory degradation products in biomass hydrolysates. Biotechnol Bioeng. 2010;107:430-40.

53. Fischer F, Mutschler J, Zufferey D. Enzyme catalysis with small ionic liquid quantities. J Ind Microbiol Biotechnol. 2011;38:477-87.

54. Vester JK, Glaring MA, Stougaard P. Discovery of novel enzymes with industrial potential from a cold and alkaline environment by a combination of functional metagenomics and culturing. Microb Cell Fact. 2014;13:72.

55. Haki G. Developments in industrially important thermostable enzymes: a review. Bioresour Technol. 2003;89:17-34.

56. Białkowska AM, Cieśliński H, Nowakowska KM, Kur J, Turkiewicz M. A new $\beta$-galactosidase with a low temperature optimum isolated from the Antarctic Arthrobacter sp. 20B: gene cloning, purification and characterization. Arch Microbiol. 2009;191:825-35.

57. Coker JA, Brenchley JE. Protein engineering of a cold-active $\beta$-galactosidase from Arthrobacter sp. SB to increase lactose hydrolysis reveals new sites affecting low temperature activity. Extremophiles. 2006;10:515-24.

58. Sørensen HP, Porsgaard TK, Kahn RA, Stougaard P, Mortensen KK, Johnsen MG. Secreted $\beta$-galactosidase from a Flavobacterium sp. isolated from a low-temperature environment. Appl Microbiol Biotechnol. 2006;70:548-57.

59. Wang G, Gao Y, Hu B, Lu X, Liu X, Jiao B. A novel cold-adapted $\beta$-galactosidase isolated from Halomonas sp. S62: gene cloning, purification and enzymatic characterization. World J Microbiol Biotechnol. 2013:29:1473-80 